\title{
Effects of the 2008 High-Flow Experiment on Water Quality in Lake Powell and Glen Canyon Dam Releases, Utah-Arizona
}

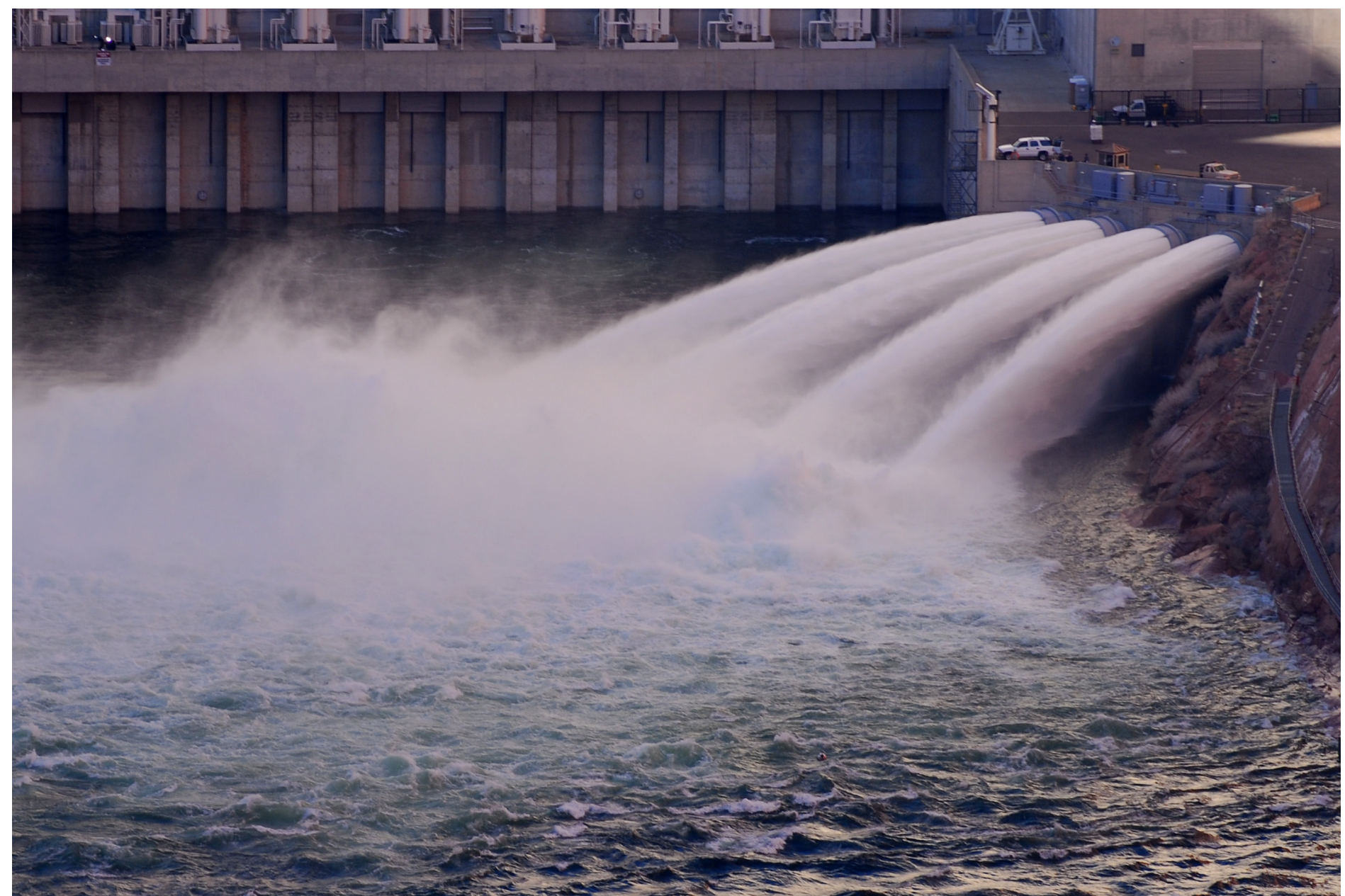

Open-File Report 2010-1159 
Cover: Glen Canyon Dam releases high flows on March 7, 2008 (USGS photo by Anne Phillips). 


\section{Effects of the 2008 High-Flow Experiment on Water Quality in Lake Powell and Glen Canyon Dam Releases, Utah-Arizona}

By William S. Vernieu

Open-File Report 2010-1159

U.S. Department of the Interior

U.S. Geological Survey 


\section{U.S. Department of the Interior \\ KEN SALAZAR, Secretary}

\section{U.S. Geological Survey \\ Marcia K. McNutt, Director}

U.S. Geological Survey, Reston, Virginia 2010

For product and ordering information:

World Wide Web: http://www.usgs.gov/pubprod

Telephone: 1-888-ASK-USGS

For more information on the USGS-the Federal source for science about the Earth,

its natural and living resources, natural hazards, and the environment:

World Wide Web: http://www.usgs.gov

Telephone: 1-888-ASK-USGS

Suggested citation:

Vernieu, W.S., 2010, Effects of the 2008 high-flow experiment on water quality in Lake Powell and Glen Canyon Dam releases, Utah-Arizona: U.S. Geological Survey Open-File Report 2010-1159, 25 p.

Any use of trade, product, or firm names is for descriptive purposes only and does not imply endorsement by the U.S. Government.

Although this report is in the public domain, permission must be secured from the individual copyright owners to reproduce any copyrighted material contained within this report. 


\section{Contents}

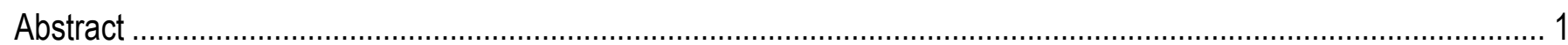

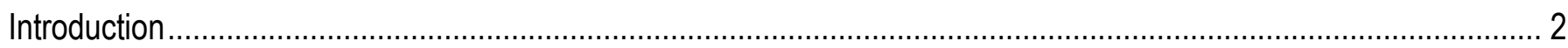

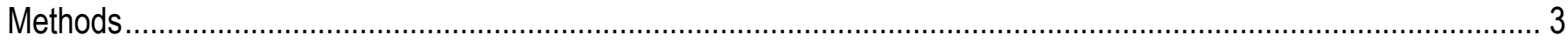

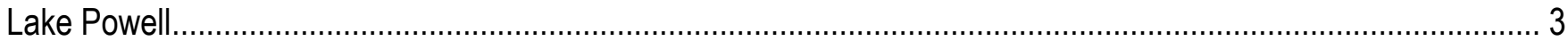

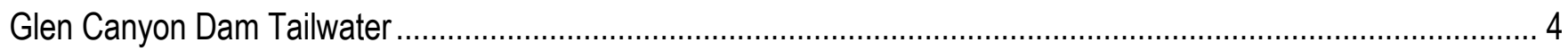

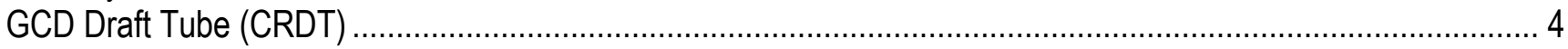

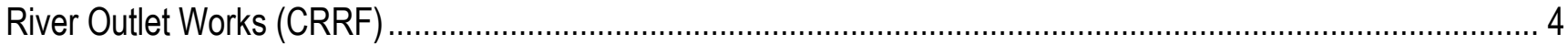

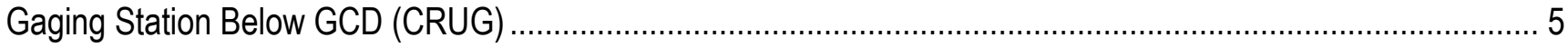

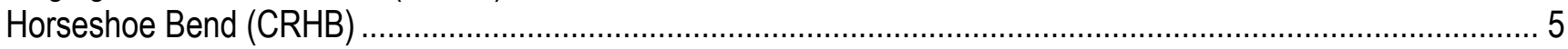

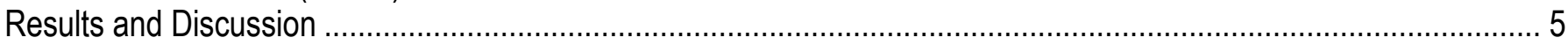

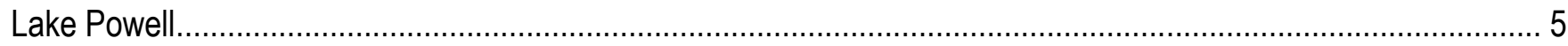

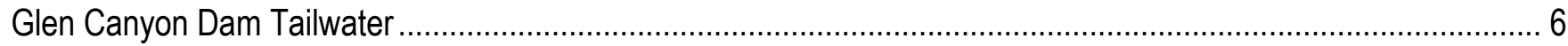

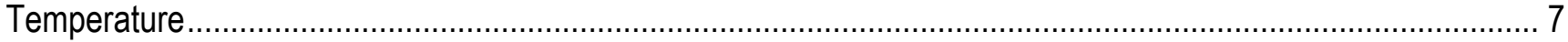

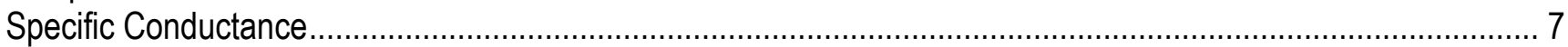

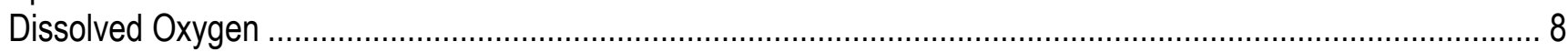

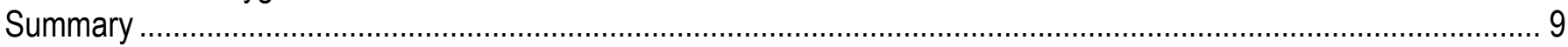

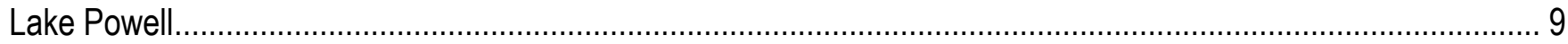

Glen Canyon Dam Tailwater …............................................................................................................

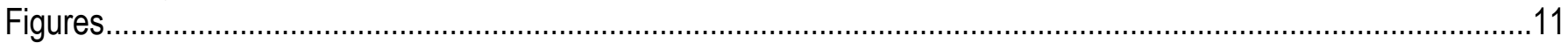

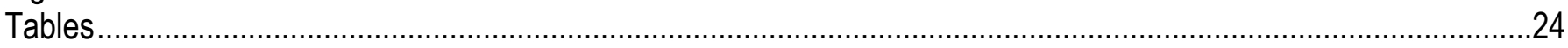

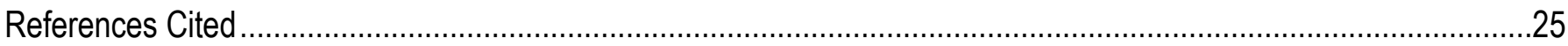

\section{Figures}

1. Location map showing lower Lake Powell and tailwater monitoring locations.

2. Powerplant, river outlet works, and combined releases from Glen Canyon Dam and Lake Powell surface elevation before, during, and after the Glen Canyon Dam high-flow experiment, conducted March 5, 2008, through March 9, 2008

3. Depth profile of water temperature, specific conductance, and dissolved oxygen at the Wahweap forebay station before and after the Glen Canyon Dam high-flow experiment, conducted March 5, 2008, through March 9, 2008

4. Depth profile of water temperature, specific conductance, and dissolved oxygen at the Romano Narrows station before and after the Glen Canyon Dam high-flow experiment, conducted March 5, 2008, through March 9, 2008 
5. Depth profile of water temperature, specific conductance, and dissolved oxygen at the Crossing of the Fathers station before and after the Glen Canyon Dam high-flow experiment, conducted March 5, 2008, through March 9, 2008.

6. Depth profile of water temperature, specific conductance, and dissolved oxygen at the Oak Canyon station before and after the Glen Canyon Dam high-flow experiment, conducted March 5, 2008, through March 9 , 2008 16

7. Depth profile of water temperature, specific conductance, and dissolved oxygen at the San Juan Confluence station before and after the Glen Canyon Dam high-flow experiment, conducted March 5, 2008, through March 9, 2008. 17

8. Isopleths of water temperature in Lake Powell before and after he Glen Canyon Dam high-flow experiment, conducted March 5, 2008, through March 9, 2008. 18

9. Isopleths of specific conductance in Lake Powell before and after the Glen Canyon Dam high-flow experiment, conducted March 5, 2008, through March 9, 2008. 19

10. Isopleths of dissolved oxygen in Lake Powell before and after the Glen Canyon Dam high-flow experiment, conducted March 5, 2008, through March 9, 2008.

11. Combined water temperature in the tailwater before, during, and after the Glen Canyon Dam high-flow experiment, conducted March 5, 2008, through March 9, 2008

12. Combined specific conductance in the tailwater before, during, and after the Glen Canyon Dam high-flow experiment, conducted March 5, 2008, through March 9, 2008 22

13. Combined dissolved oxygen concentrations in the tailwater before, during, and after the Glen Canyon Dam high-flow experiment, March 5, 2008, through March 9, 2008 23

\section{Tables}

1. Lake Powell main channel monitoring locations. 24 
2. Tailwater monitoring locations and river-channel distance in kilometers downstream from Glen Canyon Dam 24

3. Lake Powell depth profiles before and after the Glen Canyon Dam high-flow experiment, March 5, 2008, through March 9, 2008. 24

4. Average values of water temperature, specific conductance, and dissolved oxygen at selected locations during the Glen Canyon Dam high-flow experiment, conducted March 5, 2008, through March 9, 2008 ....... 24

5. Values of water temperature, specific conductance, and dissolved oxygen at selected locations before, during, and after the Glen Canyon Dam high-flow experiment, conducted March 5, 2008, through March 9 , 2008 


\section{Conversion Factors}

SI to Inch/Pound

\begin{tabular}{lcl}
\hline \multicolumn{1}{c}{ Multiply } & By & \multicolumn{1}{c}{ To obtain } \\
\hline meter $(\mathrm{m})$ & Length & \\
kilometer $(\mathrm{km})$ & 3.281 & foot $(\mathrm{ft})$ \\
& 0.6214 & mile $(\mathrm{mi})$ \\
\hline hectare $(\mathrm{ha})$ & Area & \\
\hline & 2.471 & acre \\
\hline cubic meter $\left(\mathrm{m}^{3}\right)$ & Volume & \\
cubic kilometer $\left(\mathrm{km}^{3}\right)$ & 0.0008107 & acre-foot $($ acre- $\mathrm{ft})$ \\
cubic kilometer $\left(\mathrm{km}^{3}\right)$ & 810,700 & acre-foot $($ acre- $\mathrm{ft})$ \\
\hline & 0.8107 & million-acre-feet $(\mathrm{Maf})$ \\
\hline cubic meter per second $\left(\mathrm{m}^{3} / \mathrm{s}\right)$ & Flow rate & \\
\hline
\end{tabular}

Temperature in degrees Celsius $\left({ }^{\circ} \mathrm{C}\right)$ may be converted to degrees Fahrenheit $\left({ }^{\circ} \mathrm{F}\right)$ as follows:

${ }^{\circ} \mathrm{F}=\left(1.8 \mathrm{x}^{\circ} \mathrm{C}\right)+32$

Specific conductance is given in microsiemens per centimeter at 25 degrees Celsius $\left(\mu \mathrm{S} / \mathrm{cm}\right.$ at $\left.25^{\circ} \mathrm{C}\right)$.

Concentrations of chemical constituents in water are given either in milligrams per liter $(\mathrm{mg} / \mathrm{L})$ or micrograms per liter $(\mu \mathrm{g} / \mathrm{L})$.

Vertical coordinate information is referenced to the insert datum name (and abbreviation) here, for instance, "North American Vertical Datum of 1988 (NAVD 88)"

Horizontal coordinate information is referenced to the insert datum name (and abbreviation) here, for instance, "North American Datum of 1983 (NAD 83)" 


\title{
Effects of the 2008 High-Flow Experiment on Water Quality in Lake Powell and Glen Canyon Dam Releases, Utah-Arizona
}

\author{
By William S. Vernieu
}

\begin{abstract}
Under the direction of the Secretary of the Interior, the U.S. Geological Survey's Grand Canyon Monitoring and Research Center (GCMRC) conducted a high-flow experiment (HFE) at Glen Canyon Dam (GCD) from March 4 through March 9, 2008. This experiment was conducted under enriched sediment conditions in the Colorado River within Grand Canyon and was designed to rebuild sandbars, aid endangered humpback chub (Gila cypha), and benefit various downstream resources, including rainbow trout (Oncorhynchus mykiss), the aquatic food base, riparian vegetation, and archaeological sites. During the experiment, GCD discharge increased to a maximum of $1,160 \mathrm{~m}^{3} / \mathrm{s}$ and remained at that rate for 2.5 days by near-capacity operation of the hydroelectric powerplant at $736 \mathrm{~m}^{3} / \mathrm{s}$, augmented by discharge from the river outlet works (ROW) at $424 \mathrm{~m}^{3} / \mathrm{s}$. The ROW releases water from Lake Powell approximately $30 \mathrm{~m}$ below the powerplant penstock elevation and bypasses the powerplant turbines. During the HFE, the surface elevation of Lake Powell was reduced by $0.8 \mathrm{~m}$.

This report describes studies that were conducted before and after the experiment to determine the effects of the HFE on (1) the stratification in Lake Powell in the forebay immediately upstream of GCD and (2) the water quality of combined GCD releases and changes that occurred through the tailwater below the dam. The effects of the HFE to the water quality and stratigraphy in the water column of the GCD forebay and upstream locations in Lake Powell were minimal, compared to those during the beach/habitat-building flow experiment conducted in 1996, in which high releases of 1,273 $\mathrm{m}^{3} / \mathrm{s}$ were sustained for a 9-day period. However, during the $2008 \mathrm{HFE}$, there was evidence of increased advective transport of reservoir water at the penstock withdrawal depth and subsequent mixing of this withdrawal current with water above and below this depth. Reservoir hydrodynamics during the HFE period were largely being controlled by a winter inflow density current, which was moving through the deepest portion of the reservoir and approaching GCD near the end of the experiment. Compared to the beach/habitat-building flow experiment of 1996, the $2008 \mathrm{HFE}$ had less affect on the reservoir because of the decreased volume of discharge from the dam and the different behavior of the winter inflow density current.

The operation of the ROW increased the dissolved oxygen (DO) concentration of GCD releases and resulted in DO supersaturation at higher release volumes. The jets of water discharged from the ROW caused these increases. Elevated DO concentrations persisted through the tailwater of the dam to Lees Ferry. At maximum ROW operation, downstream DO concentrations increased to approximately 120 percent of saturation.
\end{abstract}




\section{Introduction}

Under the direction of the Secretary of the Interior, the U.S. Geological Survey's (USGS) Grand Canyon Monitoring and Research Center (GCMRC) conducted a high-flow experiment (HFE) at Glen Canyon Dam (GCD) from March 4 through March 9, 2008. This experiment was conducted under enriched sediment conditions in the Colorado River within Grand Canyon and was designed to rebuild sandbars, aid endangered humpback chub (Gila cypha), and benefit various downstream resources, including rainbow trout (Oncorhynchus mykiss), the aquatic food base, riparian vegetation, and archaeological sites (U.S. Geological Survey, 2007).

GCD has a structural height of $216 \mathrm{~m}$. This high concrete arch dam backs up water for $299 \mathrm{~km}$ to form Lake Powell, the second largest reservoir in the United States. Lake Powell has a maximum depth immediately upstream of GCD of approximately $157 \mathrm{~m}$, a capacity of $32.2 \mathrm{~km}^{3}$, and a surface area of 65,315 ha at full pool elevation of $1,128 \mathrm{~m}$. Water can be released from GCD through three separate structures. The majority of water is routed through eight penstocks, which feed the powerplant turbines. The penstock inlets are at an elevation of $1,058 \mathrm{~m}$ and have a maximum combined discharge capacity of approximately $940 \mathrm{~m}^{3} / \mathrm{s}$ when the reservoir is full. Water can also be released from the river outlet works (ROW) at an elevation of 1,028 m, which bypasses the powerplant turbines and has a discharge capacity of $425 \mathrm{~m}^{3} / \mathrm{s}$ (Bureau of Reclamation, 1981; Ferrari, 1988). Two spillways, controlled by radialarm gates, can also release water from elevations above $1,112 \mathrm{~m}$, but these have been inoperable since 2002 because of drought-induced low-reservoir elevations.

Water-quality conditions in Lake Powell, which vary with season and with hydrologic and meteorological conditions, determine the quality of water that is discharged from GCD at the powerplant penstock and ROW withdrawal elevations (Vernieu and others, 2005). Above-normal discharges from GCD can cause increased mixing in the reservoir and result in increased advection, or the movement of horizontal currents through the reservoir, at withdrawal-structure elevations. Antecedent reservoir conditions and the timing, duration, and magnitude of high-volume releases can further affect the water quality of the reservoir and subsequent downstream releases (Hueftle and Stevens, 2001).

The 2008 HFE was characterized by an increase in GCD releases with the combination of approximately $425 \mathrm{~m}^{3} / \mathrm{s}$ from the ROW and approximately $736 \mathrm{~m}^{3} / \mathrm{s}$ from the GCD powerplant, for a combined release of about 1,160 m³ $/ \mathrm{s}$ for 2.5 days (60 hours) from March 6 at 5:00 a.m. to March 8 at 4:00 p.m. (fig. 2). The entire experiment lasted 4.7 days (113 hours). Powerplant discharge increased above normal operational patterns on March 4 at 9:00 p.m. and returned to normal operation on March 9 at 2:00 p.m. Releases from the ROW began on March 5 at 9:00 a.m. and stopped on March 9 at 1:00 a.m. The ROW withdraws water from an elevation approximately $30 \mathrm{~m}$ below the powerplant penstock. Therefore, releases from this structure can be expected to have lower water temperature and dissolved oxygen (DO) concentrations and higher specific conductance compared to powerplant releases, on the basis of long-term-monitoring observations (Vernieu, 2009).

During the experiment, the surface elevation of Lake Powell dropped from 1,094.49 $\mathrm{m}$ on March 4 at 9:00 p.m. to 1,093.70 m on March 9 at 2:00 p.m., a reduction of $0.79 \mathrm{~m}$, with a total volume of $0.396 \mathrm{~km}^{3}$ released during the 113 -hour period. Of this figure, $0.281 \mathrm{~km}^{3}$ was released through the powerplant and $0.115 \mathrm{~km}^{3}$ was released from the ROW. The withdrawal of water from the ROW level, combined with increased discharge from the penstock withdrawal elevation, could result in changes to the stratification of Lake Powell and to withdrawal currents within the reservoir from increased advection at these levels and increased mixing of water from above and below these structures.

Below the dam, the water quality of the combined releases from GCD can be influenced by the addition of ROW releases from a deeper portion of the reservoir and by the turbulence in the tailwater 
from ROW releases entering the Colorado River. In addition, the high discharge from combined dam releases can result in decreased travel time from GCD to Lees Ferry. This set of conditions can reduce the effect of biological processes such as photosynthesis and respiration on DO concentrations and can also reduce the amount of warming from atmospheric equilibration in that reach of the river.

In order to determine and quantify the effect of the 2008 HFE on water quality in Lake Powell and in downstream releases, monitoring and research activities focused on three areas:

- changes to water quality and stratification patterns in Lake Powell below the confluence of the San Juan River arm to GCD;

- changes to temperature, specific conductance, and DO in dam releases immediately below GCD from the combination of ROW releases with powerplant releases; and

- changes to temperature, specific conductance, and DO in dam releases through the tailwater reach between GCD and Lees Ferry from atmospheric equilibration, primary production, or additional inputs.

\section{Methods}

\section{Lake Powell}

Depth profiles were collected before the HFE as part of the GCMRC's routine Lake Powell water-quality monitoring survey conducted from February 26 to March 2, 2008. During this survey, samples and measurements were collected at 14 locations in the Colorado River main channel upstream from GCD to the inflow area of Lake Powell, approximately $241 \mathrm{~km}$ upstream from GCD. Additional samples and measurements were collected in the San Juan River, Escalante River, and Navajo Canyon arms of the reservoir. To determine the effects of the HFE on the stratification and quality of water in Lake Powell upstream of GCD, 5 of the 14 routinely monitored locations in the main channel of the Colorado River from the GCD forebay to the confluence with the San Juan River arm of Lake Powell, approximately $100 \mathrm{~km}$ upstream from GCD, were selected for comparison of pre- and post-HFE conditions (table 1, fig. 1). These five locations were resampled after the HFE in a separate survey conducted between March 9 and March 11, 2008. Locations upstream of the San Juan confluence were not evaluated because it was assumed that effects of the dam withdrawals would not be discernable and advective inflow processes would dominate upstream of this location.

Depth profiles of physical and chemical parameters were collected before and after the HFE at each study location. Only the values of water temperature, specific conductance, and DO were evaluated in this study. Water temperature and specific conductance were selected because they are the primary factors determining density in the absence of significant concentrations of suspended solids. DO was selected because it can indicate the general source of the water, that is, from recent inflows or older hypolimnetic layers. Further details of sampling locations and profiling methodologies are described by Vernieu (2009).

Sites are identified by an eight-character station-identification code. The first four characters of the code designate the reservoir and the tributary arm in which the site is located and are followed by a four-digit number indicating the river-channel distance in tenths of km upstream of GCD (for example, "LPCR0024" designates a site 2.4 river-channel km upstream of GCD on the Colorado River arm in Lake Powell) (Vernieu, 2009). 


\section{Glen Canyon Dam Tailwater}

Data were evaluated from four locations between GCD and Lees Ferry to determine the water temperature, specific conductance, and DO of dam releases (table 2). These locations and their codes are as follows:

- CRDT - inside the dam below the turbine \#6 draft tube in the GCD powerplant,

- CRRF - inside the dam at the ring-follower gates of the ROW,

- CRUG-1.8 km downstream from GCD at the site of an inactive gaging station upstream from Lees Ferry ("upper gage"), and

- CRHB - $12.8 \mathrm{~km}$ downstream from GCD below Horseshoe Bend.

Monitoring instrumentation at all sites consisted of YSI model 6920 V2 submersible multiparameter sondes, capable of measurement and continuous logging of water temperature $\left({ }^{\circ} \mathrm{C}\right)$, specific conductance $\left(\mu \mathrm{S} / \mathrm{cm}\right.$ at $\left.25^{\circ} \mathrm{C}\right), \mathrm{DO}(\mathrm{mg} / \mathrm{L}), \mathrm{pH}$, and turbidity (NTU). Measurements were recorded continuously at 20-minute intervals. For the purposes of this study, only temperature, specific conductance, and DO were evaluated. Calibrations of specific conductance and DO were performed before and after deployment of the instruments. Temperature is a factory-calibrated parameter; therefore, no temperature calibration was performed. DO was measured with a luminescent sensor. The manufacturer's specifications for the sensors on the 6920 sondes report a temperature accuracy of $\pm 0.15^{\circ} \mathrm{C}$ with a resolution of $0.01^{\circ} \mathrm{C}$, a specific conductance accuracy of \pm 0.5 percent with a resolution of $1 \mu \mathrm{S} / \mathrm{cm}$, and a DO accuracy of \pm 1 percent with a resolution of $0.01 \mathrm{mg} / \mathrm{L}$.

\section{GCD Draft Tube (CRDT)}

Measurements were collected from water passing through the draft tube below the GCD powerplant turbine \#6 (CRDT) before, during, and after the HFE as part of the routine tailwater monitoring program. Water from this location was routed through plastic tubing to a flow cell, which contained the monitor sensors. This location represents water coming from Lake Powell at the powerplant penstock withdrawal elevation of $1,058 \mathrm{~m}$ immediately after it passes through the generator and before it is exposed to ambient atmospheric conditions. Increased DO in water from the GCD draft tubes has been observed in the past, possibly a result of aeration from turbine venting. This is most noticeable at low turbine discharges, but some venting takes place at all levels of operation. Previous studies have shown that no significant difference in water quality exists in discharges from the various turbine penstocks across the face of the dam (Hart and Sherman, 1996). During normal dam operations, the entire discharge from GCD comes from the powerplant penstocks.

\section{River Outlet Works (CRRF)}

In order to monitor the quality of releases from the ROW, a monitor was deployed inside the dam near the two ring-follower gates, each of which controls the flow of water to two of the four hollow jet valves (CRRF). Water from this location was routed through plastic tubing to a flow cell, which contained the monitor sensors. Measurements collected from this location are representative of water coming from the reservoir at an elevation of $1,028 \mathrm{~m}$, approximately $30 \mathrm{~m}$ below the withdrawal elevation of the powerplant penstocks. Although the ROW tubes were filled with water for several days before and after the HFE, actual operation of the ROW began on March 5, 2008, at 9:00 a.m. and continued until March 9, 2008, at 2:00 a.m. Therefore, measurements collected before and after these times do not represent water actively moving through the ROW and were excluded from evaluation. 


\section{Gaging Station Below GCD (CRUG)}

Measurements were collected at an inactive gaging station approximately $1.8 \mathrm{~km}$ below GCD before, during, and after the HFE. This location is a sufficient distance below GCD to allow for complete mixing of the combined ROW and powerplant discharges.

\section{Horseshoe Bend (CRHB)}

Measurements were collected below Horseshoe Bend, approximately $12.8 \mathrm{~km}$ below GCD before, during, and after the HFE. This location is a sufficient distance downstream of the CRUG location to document any changes occurring to the combined discharge in the Glen Canyon reach. Monitoring at this location for the HFE did not begin until March 4, 2008.

\section{Results and Discussion}

\section{Lake Powell}

In general, the stratigraphy of the water column in Lake Powell upstream of GCD shown in the reservoir depth profiles (table $3^{1}$, figs. $3-7$ ) was representative of routinely observed late-winter/earlyspring conditions in Lake Powell. These conditions occur shortly after the maximum extent of convective winter mixing, when cooling of the surface layer of the reservoir, or epilimnion, results in mixing down to penstock withdrawal depths or slightly lower (Vernieu, 2009). Because of surface cooling, the temperature of the mixed epilimnion approached that of deeper layers, resulting in profiles that were nearly isothermal through the water column. However, a strong stratification boundary was observed just above the penstock withdrawal zone, indicated by changes in specific conductance and DO concentrations. As much as $2^{\circ} \mathrm{C}$ of surface warming, caused by the onset of spring conditions, was observed at all stations. During the HFE, a cold underflow density current, which will be discussed in following sections, was moving through the reservoir's hypolimnion (the lowermost layer of water) and approaching the forebay of GCD (fig. 8).

At the Wahweap forebay station (LPCR0024), $2.4 \mathrm{~km}$ upstream from GCD, there was a slight reduction in DO concentration (about $1.5 \mathrm{mg} / \mathrm{L}$ ) in the bottom $10 \mathrm{~m}$ of the hypolimnion compared to concentrations higher in the hypolimnion on February 26, 2008, before the HFE. On March 9, 2008, a thicker zone of lower DO developed in the deep hypolimnion, most likely from the progressive effect of the winter inflow density current, which approached GCD between the dates of the two profiles (fig. 3). Between these dates, the approaching density current was moving downstream in the deep hypolimnion, pooling and thickening near the dam. A slight increase of DO concentrations was observed at the ROW level after the HFE, indicating replacement of water at this level with water of slightly higher DO, possibly advectively transported from upstream locations at the same depth. On February 26, 2008, a sharp transition in DO concentration and specific conductance was observed at the penstock withdrawal elevation, at the lower boundary between the metalimnion (the transition layer below the mixed epilimnion), and the hypolimnion. This gradient of upper and lower metalimnetic boundaries was reduced in the March 9, 2008, profile, possibly owing to mixing of the surrounding layers with the increased amount of water being withdrawn at the penstock elevation during the HFE.

At the Romano Narrows station (LPCR0250), $25.0 \mathrm{~km}$ upstream from GCD, the low-DO layer observed in the deep hypolimnion at the Wahweap station was not present before the HFE on March 1,

\footnotetext{
${ }^{1}$ Tables 3 and 5 are too large to include in this document and are available as downloadable Excel spreadsheets at http://pubs.usgs.gov/of/2010/1159/.
} 
2008. After the HFE, on March 11, 2008, higher DO concentrations were observed in an approximately 30-m-thick layer at the bottom of the reservoir (fig. 4). This represents the winter inflow density current approaching GCD that was not present in the pre-HFE profile. No discernable differences were observed at the ROW depth. The gradient of the metalimnetic boundaries was also reduced at this station after the HFE, more so in the upper boundary, indicating preferential mixing with water higher in the reservoir.

At the Crossing of the Fathers station (LPCR0453), $45.3 \mathrm{~km}$ upstream from GCD, the winter inflow density current was clearly visible both before and after the HFE (fig. 5). A similar reduction in the sharpness of the pre-HFE metalimnetic boundaries was seen at this location after the HFE.

At the Oak Canyon station (LPCR0905), $90.5 \mathrm{~km}$ upstream from GCD, the entire hypolimnion of the reservoir was dominated by the inflow density current before and after the HFE (fig. 6). A variable intermediate layer, approximately $20 \mathrm{~m}$ thick, representing the remnants of the previous year's hypolimnion, was located between the density current layer and the bottom layer of the mixed epilimnion. Except for an increased thickness of the density current layer after the HFE and a slight increase in surface warming, there were no appreciable differences in the water column at this location before and after the HFE.

At the San Juan Confluence station (LPCR1001), $100 \mathrm{~km}$ upstream from GCD, the hypolimnion was made up entirely of the winter inflow density current. Before the HFE, only a small layer, approximately $10 \mathrm{~m}$ thick, existed in the transition between the hypolimnion and epilimnion. This layer had been virtually evacuated in the post-HFE profile (fig. 7). A thin layer of water, 3 to $6 \mathrm{~m}$ thick, characterized by increased temperature and decreased specific conductance, was present on the surface of the reservoir in both profiles. This layer may represent influence from the San Juan River or Escalante arms of the reservoir.

Isopleths of temperature (fig. 8), specific conductance (fig. 9), and DO (fig. 10), pre- and postHFE, show the stratification in the reservoir below the mixed epilimnion, the progressive movement of the inflow density current through the reservoir, and the gradual evacuation of the previous year's hypolimnion. In each isopleth, the top graph represents conditions measured throughout the Colorado River main channel of the reservoir in the pre-HFE reservoir survey, and the bottom graph represents conditions measured from GCD to the San Juan River confluence in the post-HFE survey.

\section{Glen Canyon Dam Tailwater}

Water-quality data from continuous GCD tailwater monitoring at four locations are listed in table 5 and were graphically combined to present each of the three parameters of interest: water temperature (fig. 11), specific conductance (fig. 12), and DO (fig. 12). Horizontal lines in each figure show the value of each parameter observed in the Lake Powell forebay at the penstock and ROW withdrawal elevations on February 26, 2008. Table 4 shows data from Lake Powell at the penstock and ROW withdrawal elevations on February 26, 2008; the four tailwater locations, averaged during the HFE peak discharge period from March 6, 2008, at 6:00 a.m. to March 8, 2008, at 4:00 p.m.; and a discharge-weighted average of the combined releases during the HFE. Data from depth profiles collected in Lake Powell before and after the HFE are shown in table 3 for comparison with values recorded at CRRF and CRDT. Values from the Lake Powell forebay profile on February 26, 2008, may not coincide exactly with actual releases at the corresponding elevations, because the conditions vary significantly with depth in the stratified water column in Lake Powell and the water released from GCD may come from elevations slightly above or below the actual elevations of the discharge structures. 


\section{Temperature}

The mean water temperature during the $\mathrm{HFE}$ was higher at CRDT $\left(8.00^{\circ} \mathrm{C}\right)$ than that recorded at the penstock elevation in Lake Powell $\left(7.63^{\circ} \mathrm{C}\right)$, indicating withdrawal of water from higher in the water column than the actual penstock elevation (table 4). Water temperature in Lake Powell ranged between $7.41^{\circ} \mathrm{C}$ and $7.73^{\circ} \mathrm{C}$ in a $3-\mathrm{m}$ depth range surrounding the penstock withdrawal elevation (table 3 , fig. 3 ), indicating a stratification boundary located just above the penstock withdrawal elevation. However, water with a temperature of $8.00^{\circ} \mathrm{C}$ was not observed in the reservoir below a depth of $20 \mathrm{~m}$, approximately $16 \mathrm{~m}$ above the penstock elevation, and therefore could not have been entrained in penstock releases. This finding could indicate that some amount of artifactual warming was recorded at CRDT from ambient conditions in the tubing leading to the flow cell of the monitoring instrument.

Water temperature at CRRF increased by nearly $0.5^{\circ} \mathrm{C}$ on the morning of March 6,2008 , coincident with maximum discharge from the ROW (fig. 11). A mean value of $8.43^{\circ} \mathrm{C}$ was observed at CRRF during the HFE, compared to $7.00^{\circ} \mathrm{C}$ measured at the ROW elevation in Lake Powell (table 4). This finding is unusual because the water temperature in Lake Powell at the ROW withdrawal elevation is lower than that at the penstock withdrawal elevation. Furthermore, while observed CRRF temperatures during the $\mathrm{HFE}$ ranged between $8.3^{\circ} \mathrm{C}$ and $8.5^{\circ} \mathrm{C}$, these temperatures were not observed in Lake Powell below 8-m depth. These elevated temperatures may be the result of the water being artifactually warmed from ambient conditions in tubing leading to the flow cell of the monitoring instrument but to a much higher degree than was observed at CRDT. Therefore, these data should be regarded as artifact and not truly representative of the actual temperature of ROW releases.

There was a slight drop $\left(\sim 0.4^{\circ} \mathrm{C}\right)$ in water temperature recorded at CRDT and downstream locations, coincident with the beginning of increased powerplant releases, on the evening of March 4, 2008, and continuing through the HFE (fig. 11). This drop in temperature indicates the initial withdrawal of a deeper plume of water extending down to the actual penstock elevation and reducing release temperatures.

During the HFE, the CRUG and CRHB locations displayed temperatures that were slightly $\left(\sim 0.2^{\circ} \mathrm{C}\right)$ less than those recorded at CRDT and showed slight warming $\left(\sim 0.2^{\circ} \mathrm{C}\right)$ during daylight hours between the two locations. The slight decrease at these locations from CRDT temperatures results from the mixing of cooler ROW water with powerplant releases. When dam releases returned to normal levels on March 9, 2008, approximately $0.8^{\circ} \mathrm{C}$ of warming was observed at the CRHB location during daylight hours, followed by approximately $0.2^{\circ} \mathrm{C}$ of cooling at night, indicating increased atmospheric equilibration in the tailwater at lower discharges and reduced travel time.

\section{Specific Conductance}

The mean specific conductance at CRDT during the HFE $(812 \mu \mathrm{S} / \mathrm{cm})$ was lower than what was measured at the penstock withdrawal elevation in Lake Powell on February 26, $2008(837 \mu \mathrm{S} / \mathrm{cm})$. Specific conductance in Lake Powell ranged between $808 \mu \mathrm{S} / \mathrm{cm}$ and $854 \mu \mathrm{S} / \mathrm{cm}$ in a 3-m depth range surrounding the penstock withdrawal elevation (table 3, fig. 3), indicating a strong stratification boundary located just above the penstock withdrawal elevation. The difference in values indicates that withdrawal through the powerplant penstocks during the HFE came from slightly higher in the water column of the reservoir than the actual penstock elevation. The mean specific conductance at CRRF during the HFE was $887 \mu \mathrm{S} / \mathrm{cm}$, compared to a value of $881 \mu \mathrm{S} / \mathrm{cm}$ measured at the ROW withdrawal elevation in Lake Powell. The similarity of these numbers is because of the lack of stratification in the reservoir at the ROW level.

There was an increase in specific conductance recorded at CRDT and downstream locations beginning on the evening of March 4, 2008 (fig. 12), which corresponds to the decreased temperature 
observed at these locations discussed in the previous section (fig. 11). This increase coincided with the beginning of increased powerplant releases (fig. 2), indicating initial withdrawal of a deeper plume of water extending down to the actual penstock elevation and incorporating water of higher specific conductance.

The discharge-weighted average of the measurements from the two release structures ( 840 $\mu \mathrm{S} / \mathrm{cm})$ compares favorably with the mean values at the two downstream locations, CRUG $(829 \mu \mathrm{S} / \mathrm{cm})$ and CRHB $(831 \mu \mathrm{S} / \mathrm{cm})$, which represent the well-mixed combined flows from each release structure (table 4). Specific conductance at the two downstream locations during the HFE was $17 \mu \mathrm{S} / \mathrm{cm}$ to 19 $\mu \mathrm{S} / \mathrm{cm}$ higher than at CRDT because of the influence of ROW discharge (table 4) and returned to similar values to CRDT after ROW discharges ceased. Unlike temperature and DO, specific conductance is a conservative parameter and not expected to be affected by external influences such as warming or aeration.

\section{Dissolved Oxygen}

There was a large difference between the mean DO concentration at CRDT during the HFE $(8.04 \mathrm{mg} / \mathrm{L})$ and what was measured at the penstock withdrawal elevation in Lake Powell on February 26, 2008 (6.08 mg/L) (table 4). DO concentration ranged between $5.80 \mathrm{mg} / \mathrm{L}$ and $6.82 \mathrm{mg} / \mathrm{L}$ in a $3-\mathrm{m}$ depth range surrounding the penstock withdrawal elevation (table 3, fig. 3). Again, the higher mean DO concentration in CRDT during the HFE compared to that observed in Lake Powell at the penstock elevation indicates that water was being withdrawn from higher elevations in the reservoir water column. However, the DO concentration at CRDT was much higher than the DO concentration in the reservoir at a depth corresponding to the observed CRDT specific conductance. Furthermore, water with a DO concentration of $8.04 \mathrm{mg} / \mathrm{L}$ or more was not observed in the reservoir below a depth of $18 \mathrm{~m}$, approximately $18 \mathrm{~m}$ above the penstock elevation. This finding could be explained by some degree of aeration of CRDT releases from turbine venting, in which the powerplant turbines draw air through their vents and aerate the water passing through the turbine. This aeration may account for the unusually high DO concentrations that were observed at CRDT. Mean DO concentrations during the HFE were 2.11 $\mathrm{mg} / \mathrm{L}$ lower at CRRF than at CRDT (table 4). Because of the lack of stratification in the reservoir at the ROW level, the mean DO concentration at CRRF (5.93 mg/L) during the HFE was comparable to measurements at the ROW elevation in the Lake Powell forebay on February 26, 2008 (5.98 mg/L).

After the ROW releases began on March 5, 2008, at 9:00 a.m., DO concentrations at CRUG and CRHB immediately increased and rose in proportion to the increasing ROW discharge (fig. 13). A mean value during the $\mathrm{HFE}$ of $12.70 \mathrm{mg} / \mathrm{L}$ was recorded at CRUG and $12.60 \mathrm{mg} / \mathrm{L}$ was recorded at CRHB (table 4). This increase was because of aeration caused by ROW releases into the river. Based on an estimated DO concentration at full saturation of $10.4 \mathrm{mg} / \mathrm{L}$, saturation values at CRUG and CRHB were 122 percent and 121 percent, respectively.

During the day before the HFE, DO concentrations at CRUG were similar to those measured at CRDT. However, at CRHB, DO concentrations were approximately $0.5 \mathrm{mg} / \mathrm{L}$ higher, indicating increases in DO from atmospheric equilibration of undersaturated releases and the contribution of primary production in the $12.8-\mathrm{km}$ reach below the dam, observable with the relatively lower discharges and increased travel time through the tailwater. A similar pattern was observed immediately after the HFE. 


\section{Summary}

\section{Lake Powell}

The effects of the $2008 \mathrm{HFE}$ on the stratigraphy of the water column in the forebay of GCD can be considered minimal compared to the beach/habitat-building flow (BHBF) experiment that occurred from March 26 through April 4, 1996 (Schmidt, 1999). One reason for this difference is that more than twice the volume of water was discharged for a 9.3-day period in 1996 compared to the 4.7-day period of the 2008 HFE. In 1996, approximately $0.899 \mathrm{~km}^{3}$ was released from GCD, with $0.627 \mathrm{~km}^{3}$ coming from the powerplant penstocks and $0.268 \mathrm{~km}^{3}$ coming from the ROW. For the $2008 \mathrm{HFE}$, approximately $0.396 \mathrm{~km}^{3}$ were released, with $0.281 \mathrm{~km}^{3}$ coming from the powerplant and $0.115 \mathrm{~km}^{3}$ from the ROW.

An additional factor contributing to the differential effects of the two experiments was antecedent reservoir conditions. During the spring of each year, from 1999 to 2008, winter inflows moving through Lake Powell were of sufficient density, relative to the receiving waters of the reservoir, to flow along the bottom of the reservoir, displacing existing water upward and downstream as this underflow current moved through the reservoir. This phenomenon was observed during the 2008 HFE study. This process can be seen as an important mixing mechanism in Lake Powell. Without an underflow current, there is no mechanism to displace dense water in the deep hypolimnion near the dam, resulting in stagnation and eventual hypoxia of this water. In contrast, no underflow density current was observed at Lake Powell from 1991 to 1998, and a stagnant body of water was in place during that period, with DO concentrations reaching as low as $1.2 \mathrm{mg} / \mathrm{L}$ in January 1996 (Hueftle and Stevens, 2001).

In the $2008 \mathrm{HFE}$, the effects of the increased powerplant discharge resulted in higher flows moving through the reservoir from upstream locations at the penstock withdrawal elevation. This condition was evidenced by increased diffusion between the layers of water above and below the withdrawal plume and the evacuation of a distinct layer of water at this elevation near the confluence with the San Juan River arm. As the body of water in the hypolimnion near the ROW withdrawal elevation was fairly homogenous before the arrival of the inflow density current, little or no effect was seen at this depth. In contrast, conditions during the 1996 BHBF were such that a dense body of hypoxic water had built up in the hypolimnion near the dam. The increased volume of water drawn through the powerplant and ROW during the $1996 \mathrm{BHBF}$ resulted in evacuation of the hypoxic water above the ROW level. In addition, during the 1996 BHBF, the winter inflows were not of sufficient density, relative to the existing hypolimnetic waters, to flow along the bottom of the reservoir and cause displacement of the deep hypolimnetic water as was seen in 2008. Instead, winter inflows in 1996 flowed through intermediate depths of the reservoir and were most likely routed directly through the penstocks and ROW, freshening the water at the depth of both structures, while leaving deeper layers stagnant. In the spring of 2008, at least some of the water withdrawn from the dam consisted of deep hypolimnetic water, which collected near the dam and was eventually displaced upward by the underflow density current. Therefore, the effects to Lake Powell from high releases at GCD are not only dependent on the volume and duration of discharge from release structures of the dam, but also on preexisting conditions associated with stratification patterns and the fate of inflow currents in the reservoir at the time of the high releases. 


\section{Glen Canyon Dam Tailwater}

The specific conductance of the combined release, measured at CRUG and CRHB, was close to what was expected from a discharge-weighted average of specific conductance from the two release structures, CRRF and CRDT (table 4). Temperature values appeared to be affected by artifactual warming in the monitoring instrument flow cells at the CRRF location. Dissolved oxygen was substantially affected by the aeration caused by the ROW discharge. As a result, the primary effect of the HFE on the water quality of GCD releases was the aeration of the undersaturated releases from both structures, which brought DO concentrations to supersaturated conditions. Dissolved oxygen concentration immediately increased with the onset of ROW releases and reached a maximum value concurrently with the maximum ROW releases. These high concentrations were observed immediately downstream at the CRUG location and persisted at the CRHB location. These results show that the operation of the ROW can be expected to aerate GCD releases and result in DO saturation or supersaturation that persists through the tailwater. 


\section{Figures}

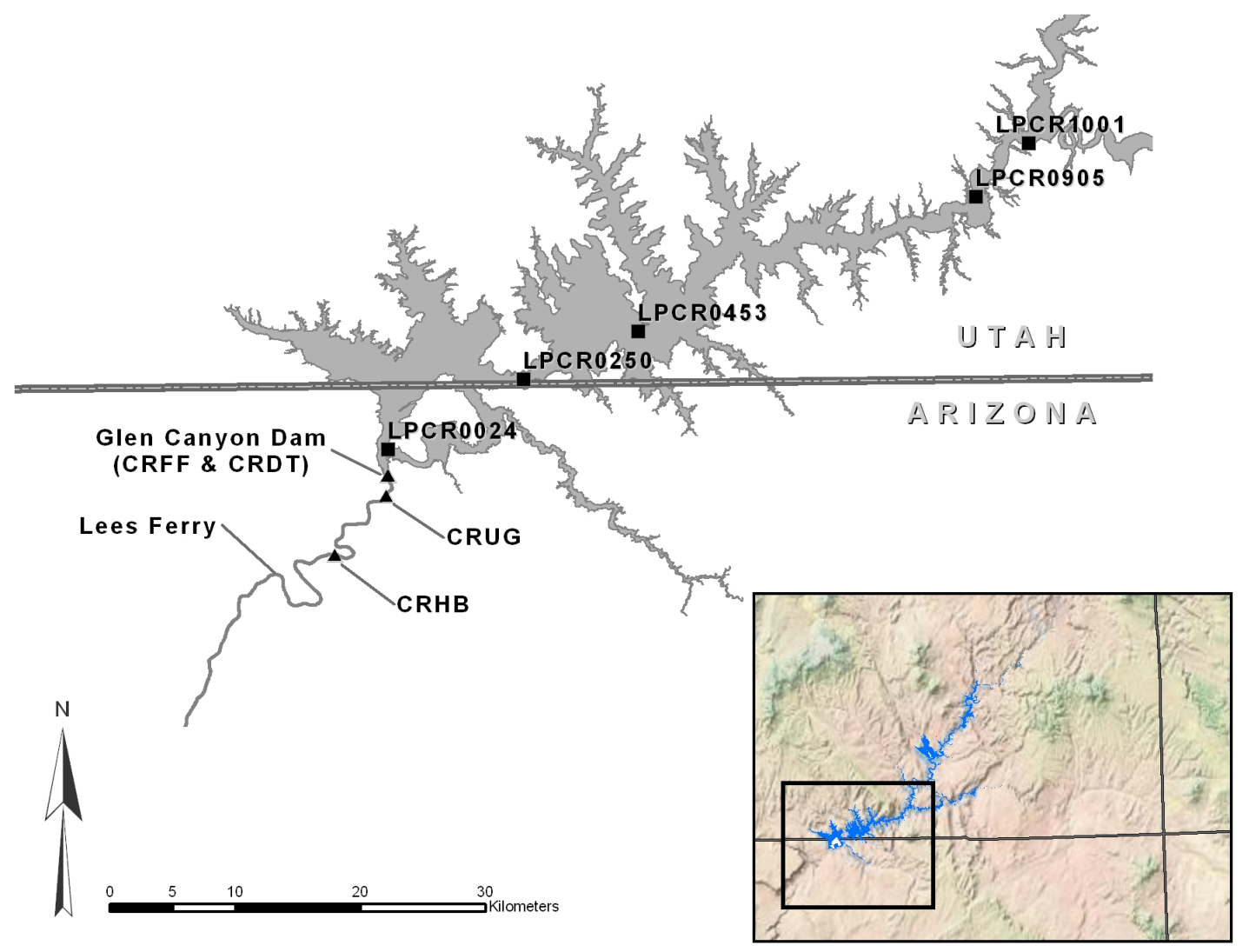

Figure 1. Location map showing lower Lake Powell and tailwater monitoring locations. 


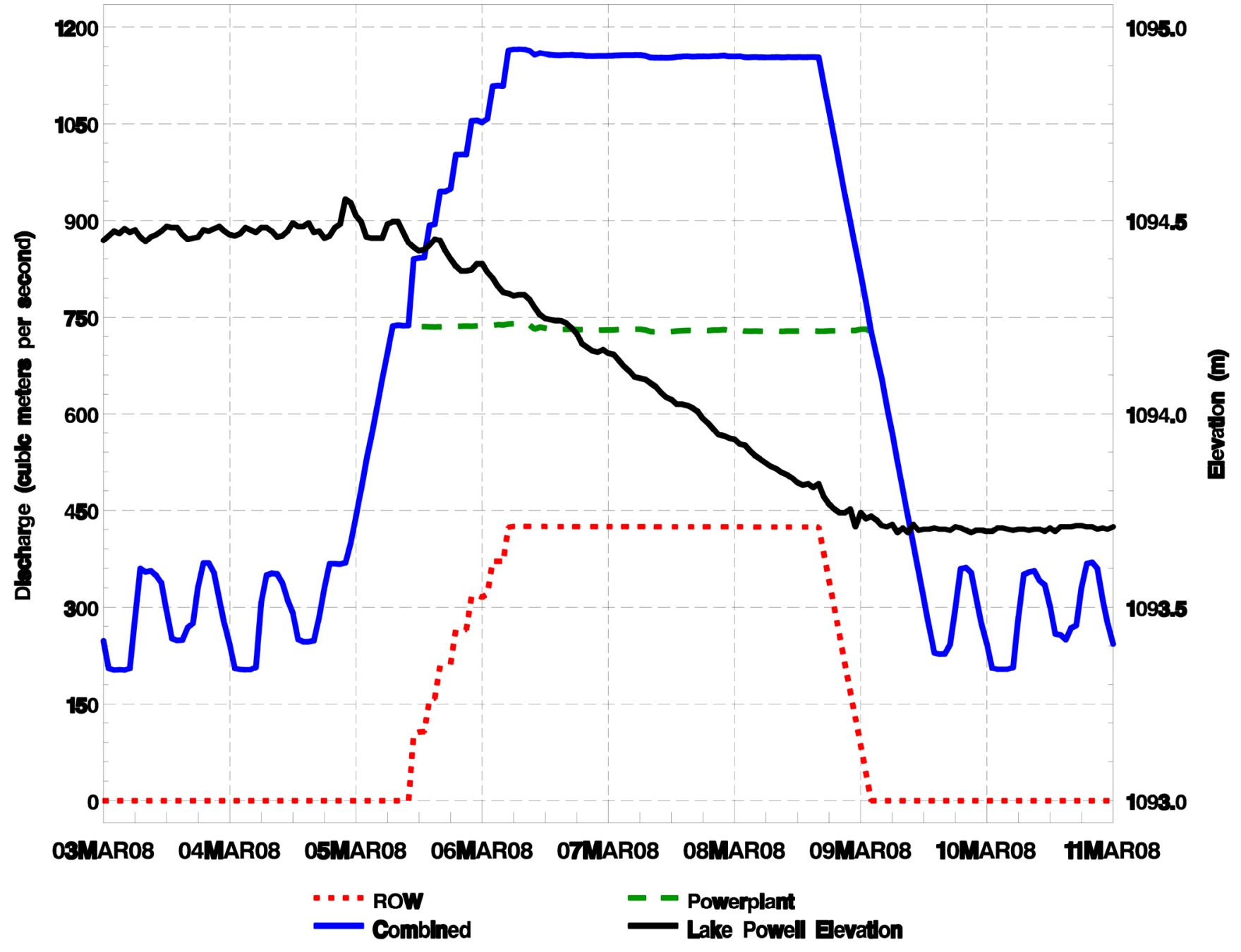

Figure 2. Powerplant, river outlet works (ROW), and combined releases from Glen Canyon Dam and Lake Powell surface elevation before, during, and after the Glen Canyon Dam high-flow experiment, conducted March 5 , 2008, through March 9, 2008. 

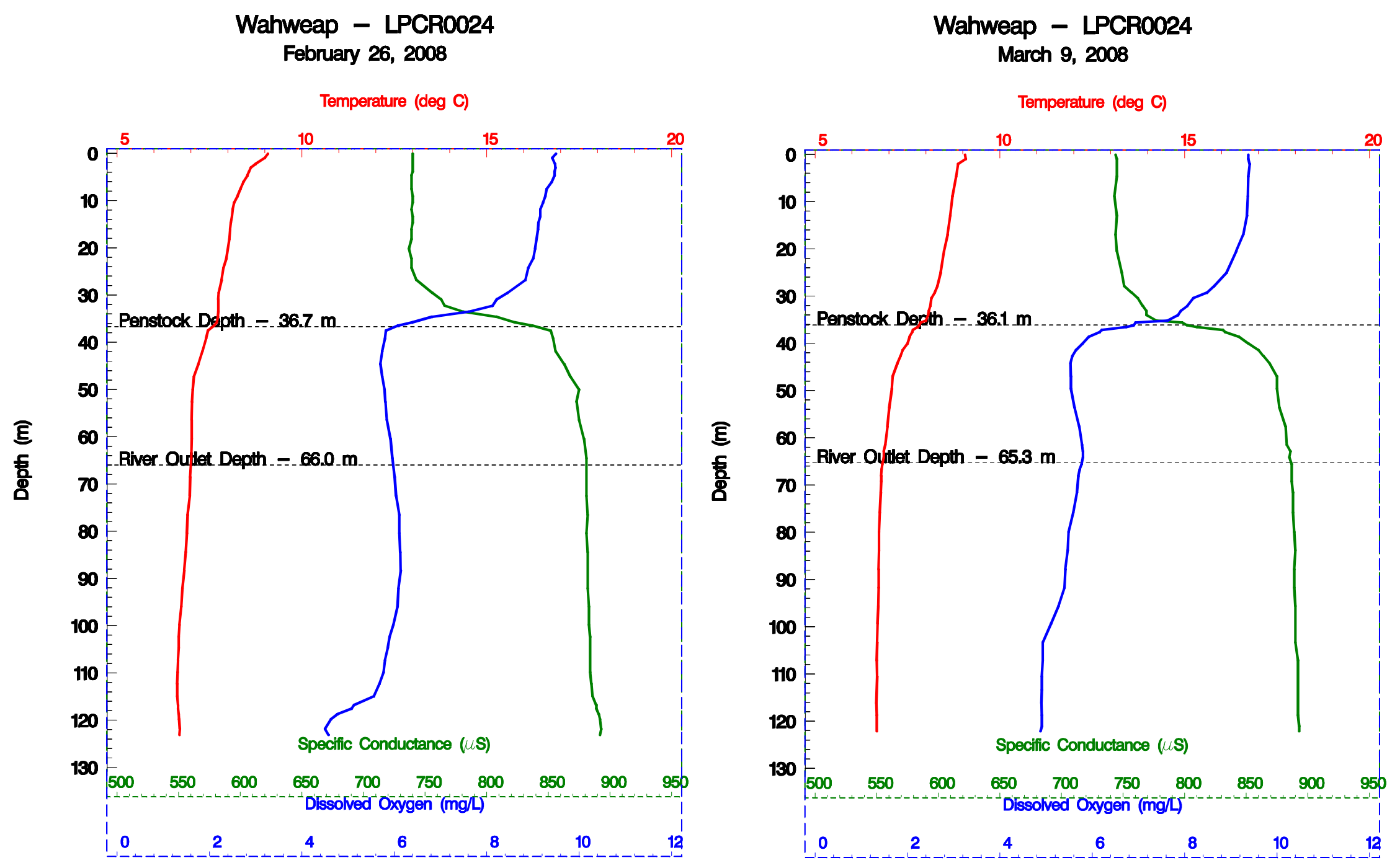

Figure 3. Depth profile of water temperature, specific conductance, and dissolved oxygen at the Wahweap forebay station (LPCR0024) before and after the Glen Canyon Dam high-flow experiment, conducted March 5, 2008, through March 9, 2008. 


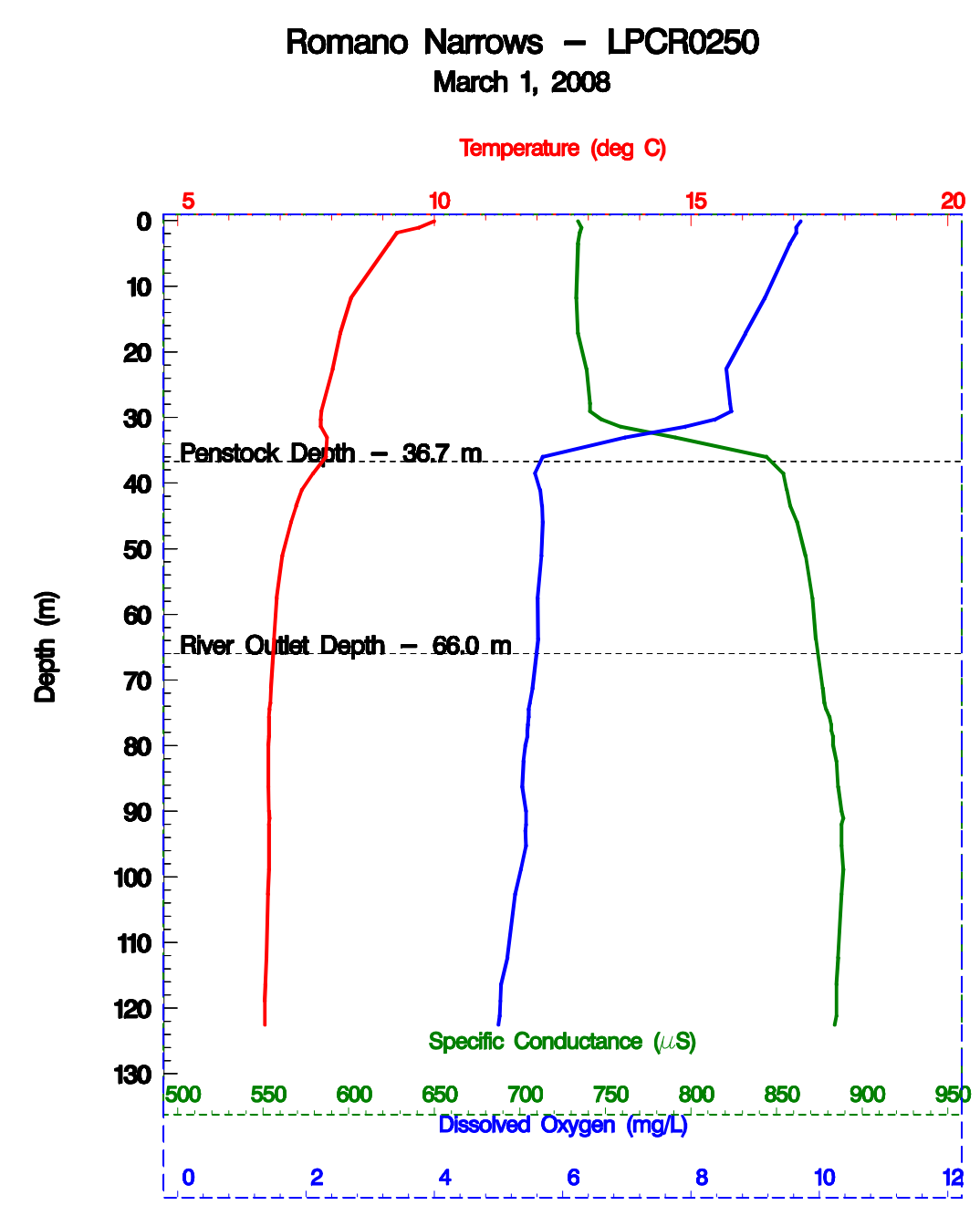

Romano Narrows - LPCR0250

March 11, 2008

Temperature (deg C)

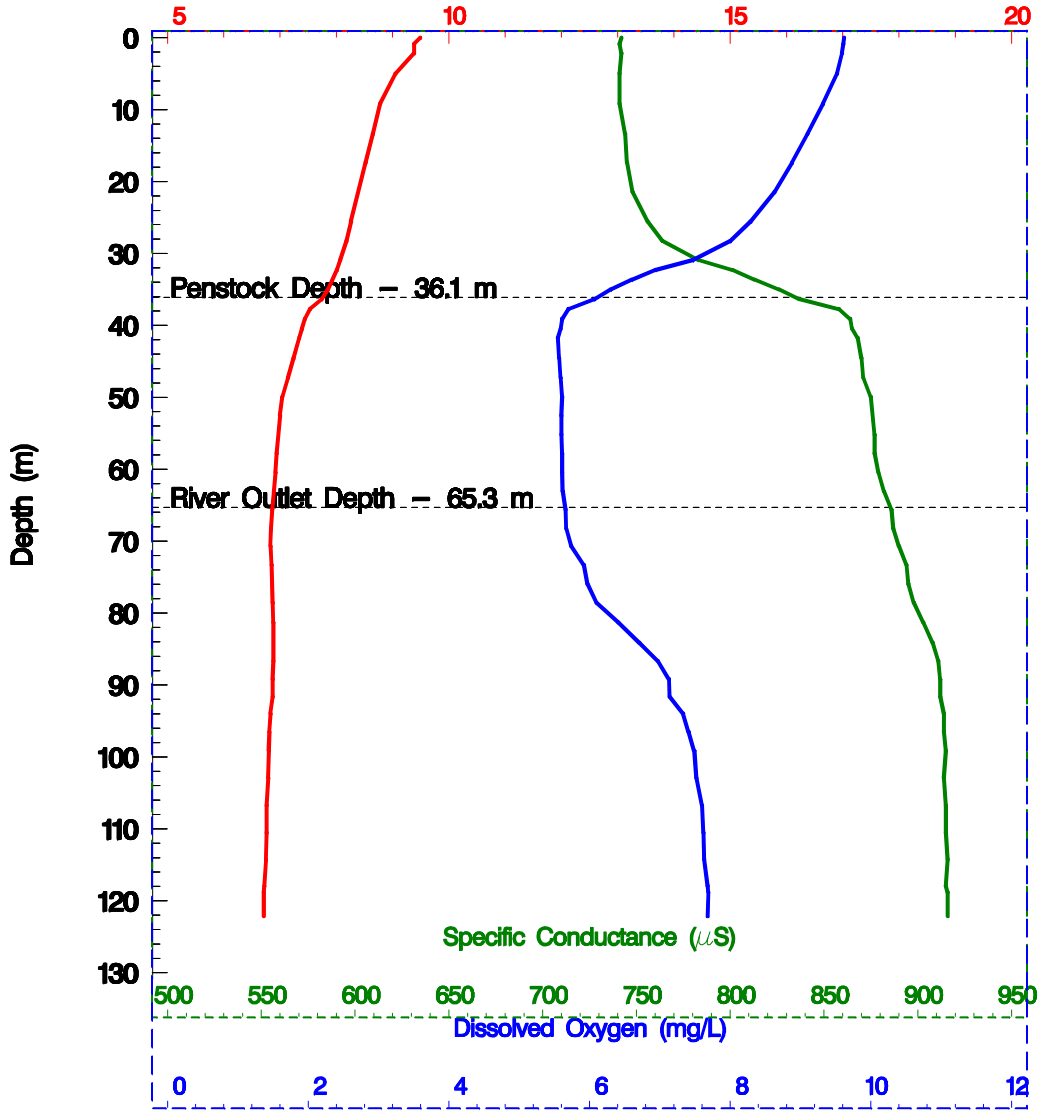

Figure 4. Depth profile of water temperature, specific conductance, and dissolved oxygen at the Romano Narrows station (LPCR0250) before and after the Glen Canyon Dam high-flow experiment, conducted March 5, 2008, through March 9, 2008. 

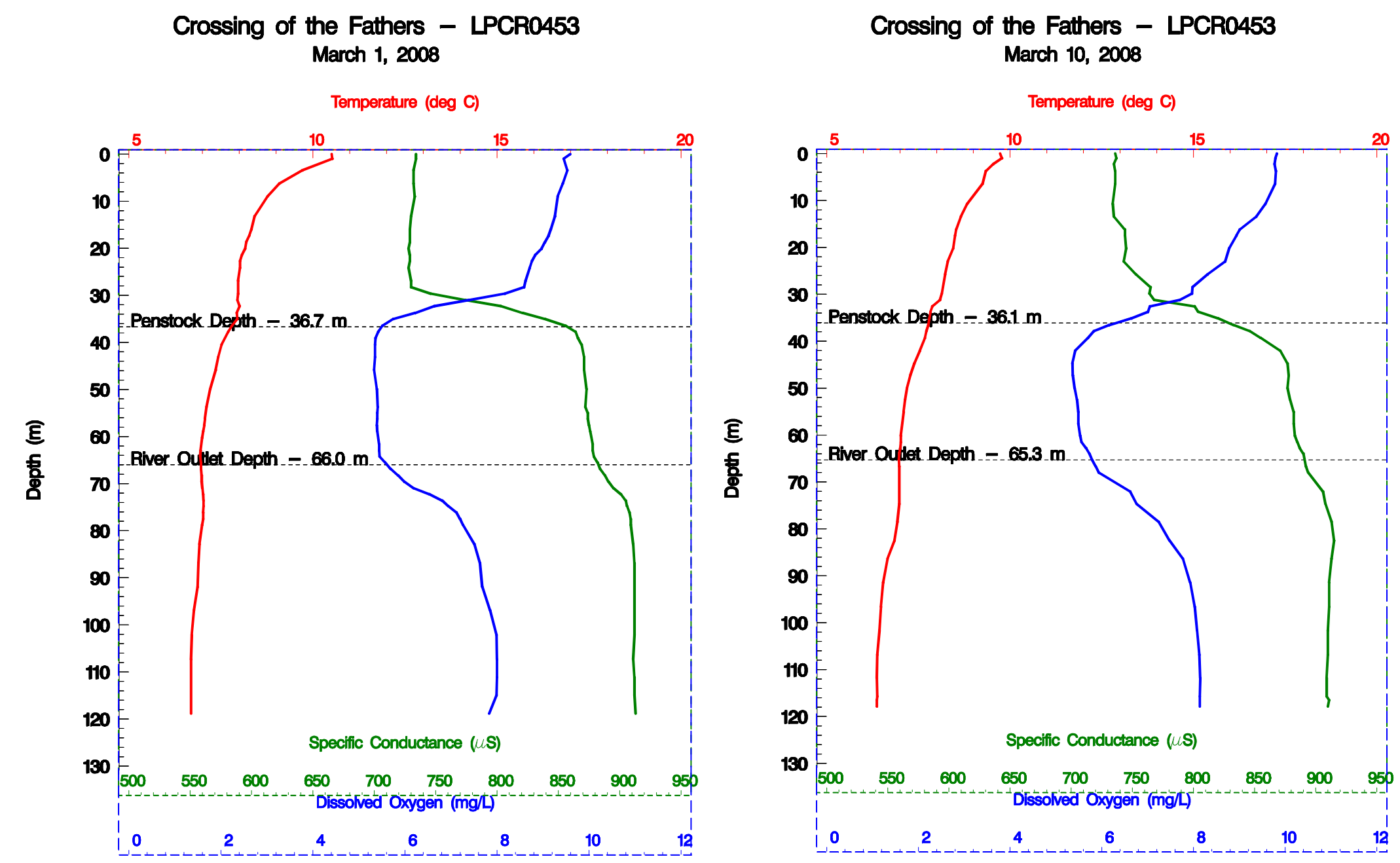

Figure 5. Depth profile of water temperature, specific conductance, and dissolved oxygen at the Crossing of the Fathers station (LPCR0453) before and after the Glen Canyon Dam high-flow experiment, conducted March 5, 2008, through March 9, 2008. 
Oak Canyon - LPCR0905

March 1, 2008

Temperature (deg C)

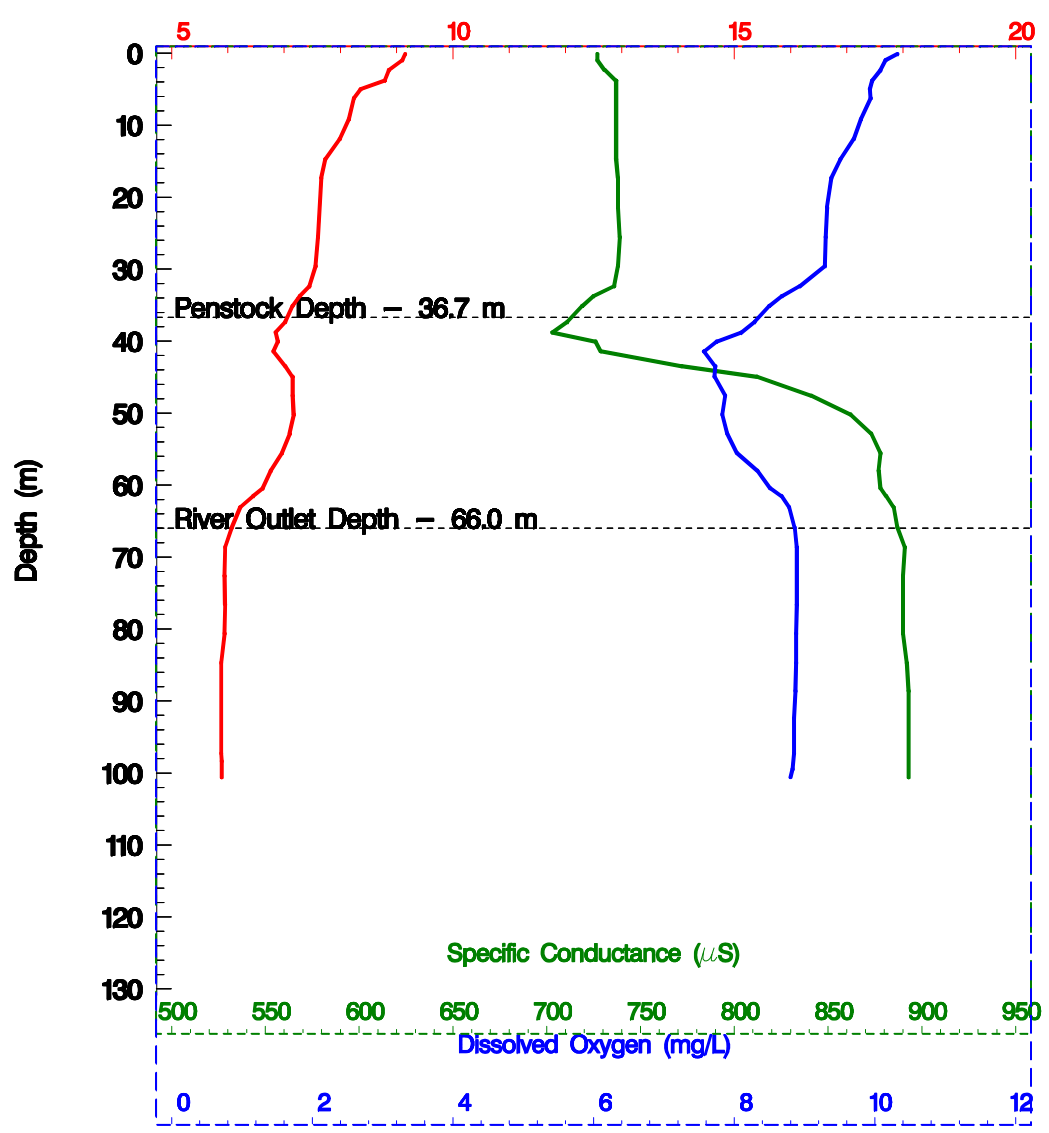

Oak Canyon - LPCR0905

March 10, 2008

Temperature (deg C)

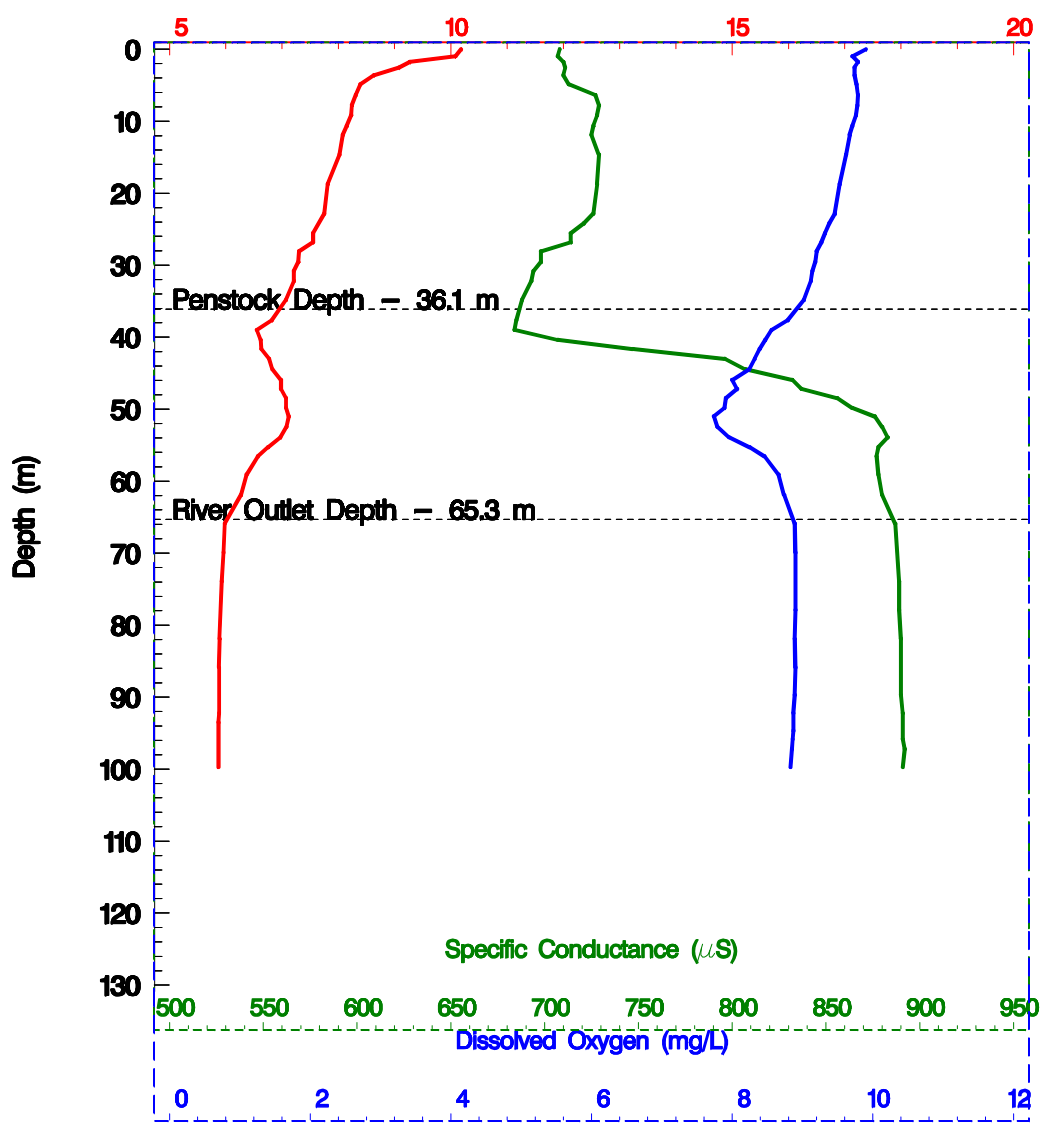

Figure 6. Depth profile of water temperature, specific conductance, and dissolved oxygen at the Oak Canyon station (LPCR0905) before and after the Glen Canyon Dam high-flow experiment, conducted March 5, 2008, through March 9, 2008. 
San Juan Confluence - LPCR1001

March 1, 2008

Temperature (deg C)

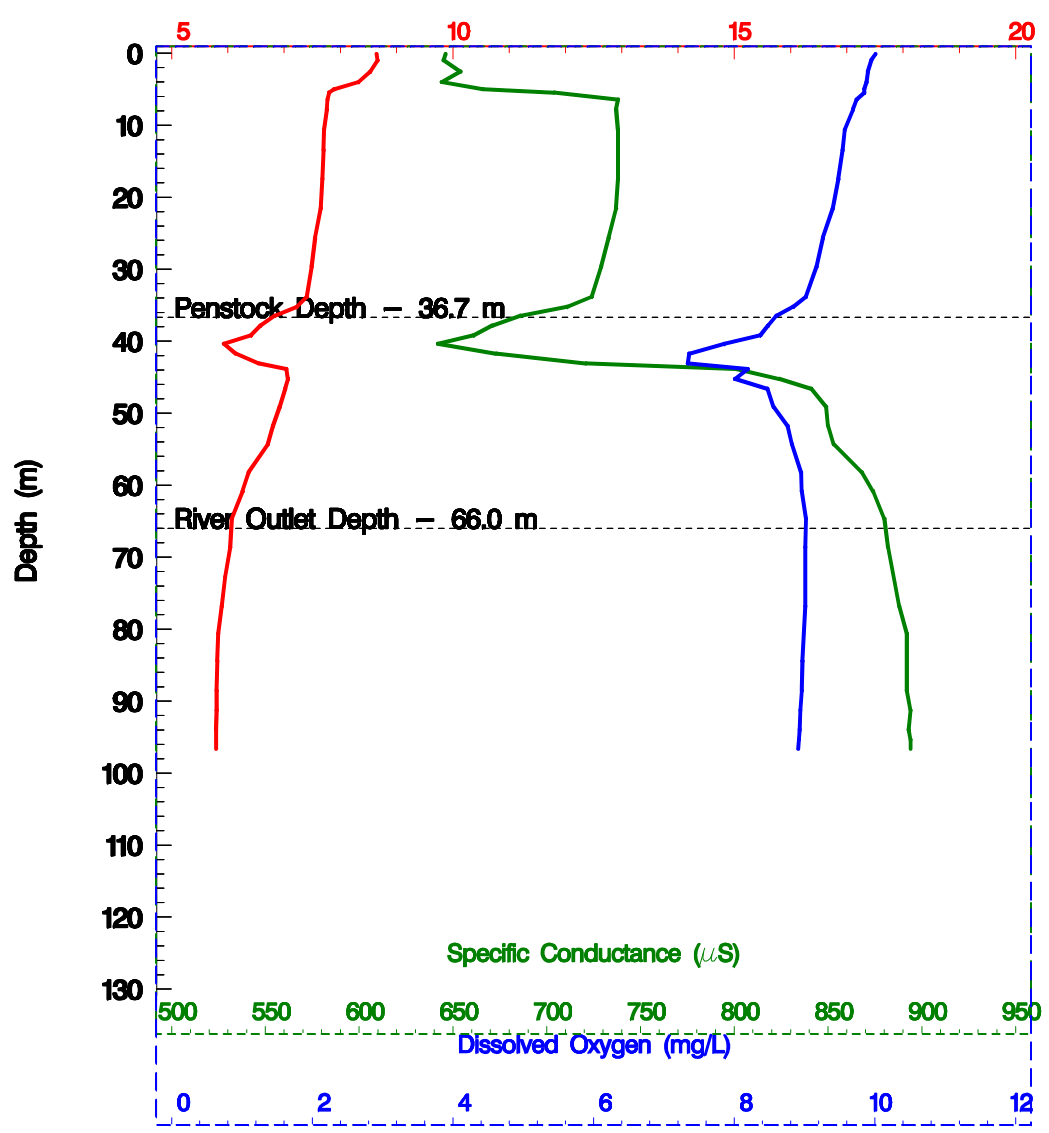

San Juan Confluence - LPCR1001

March 10, 2008

Temperature (deg C)

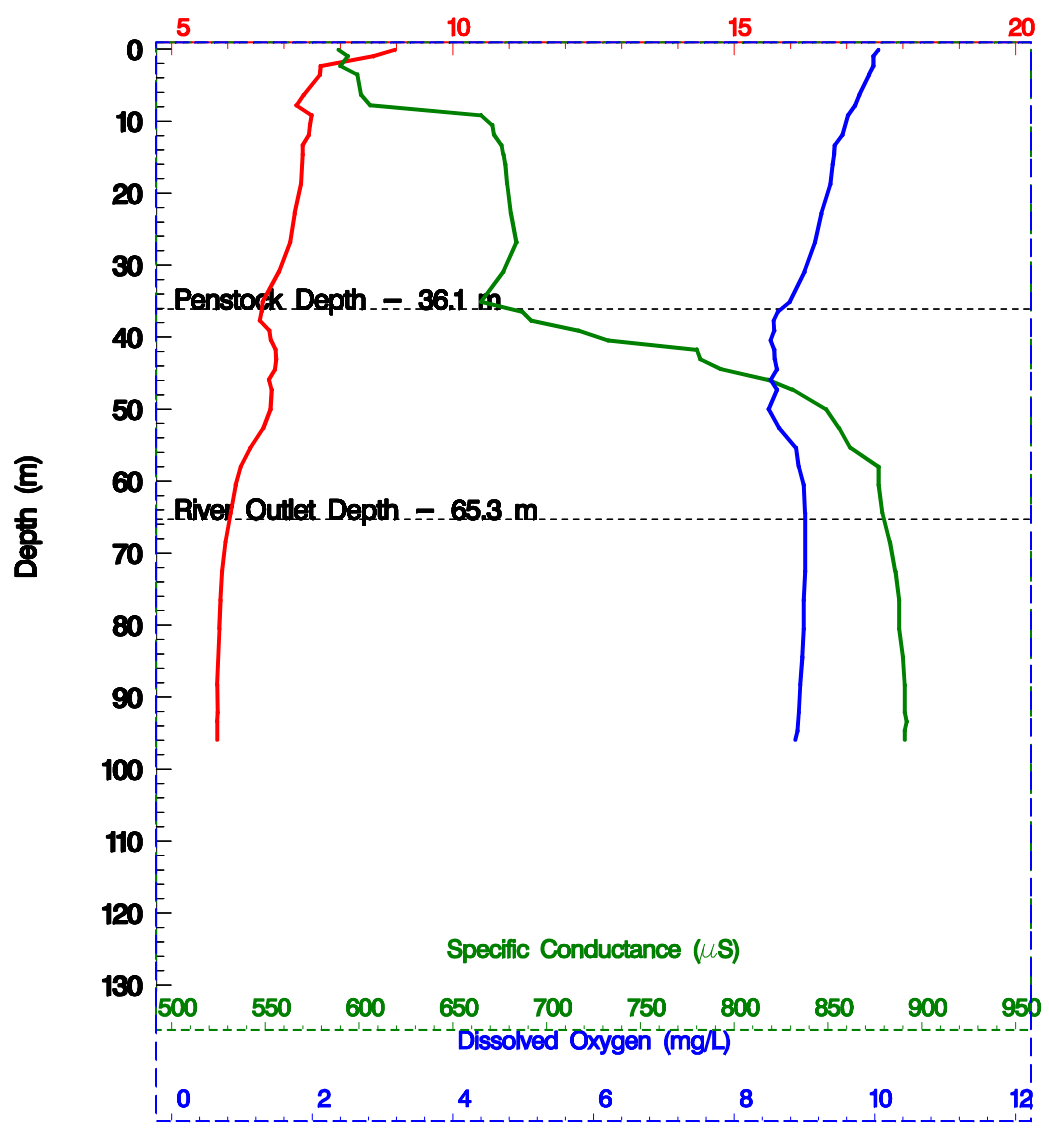

Figure 7. Depth profile of water temperature, specific conductance, and dissolved oxygen at the San Juan Confluence station (LPCR1001) before and after the Glen Canyon Dam high-flow experiment, conducted March 5, 2008, through March 9, 2008. 

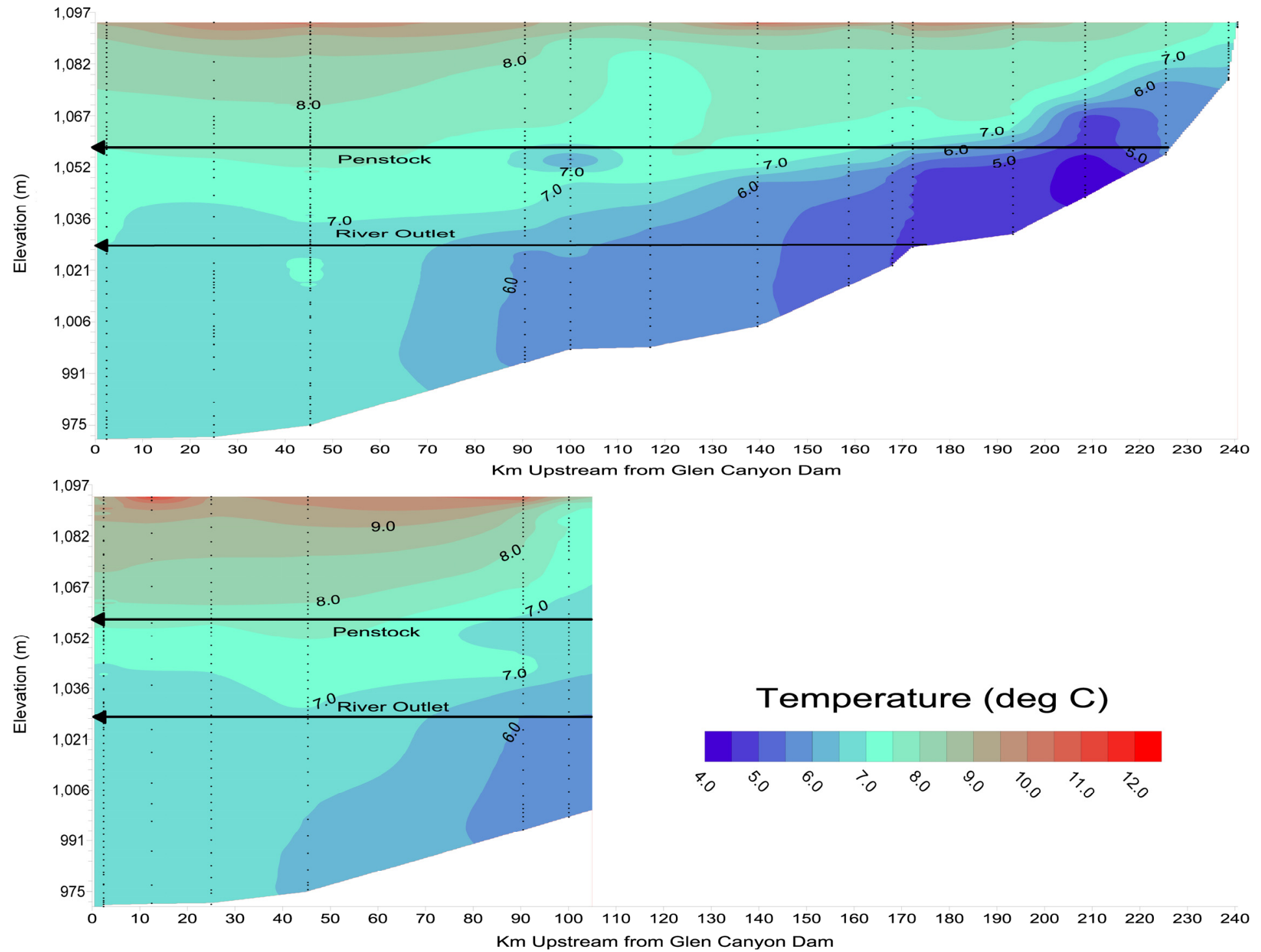

Figure 8. Isopleths of water temperature in Lake Powell before (top) and after (bottom) the Glen Canyon Dam high-flow experiment, conducted March 5, 2008, through March 9, 2008. 

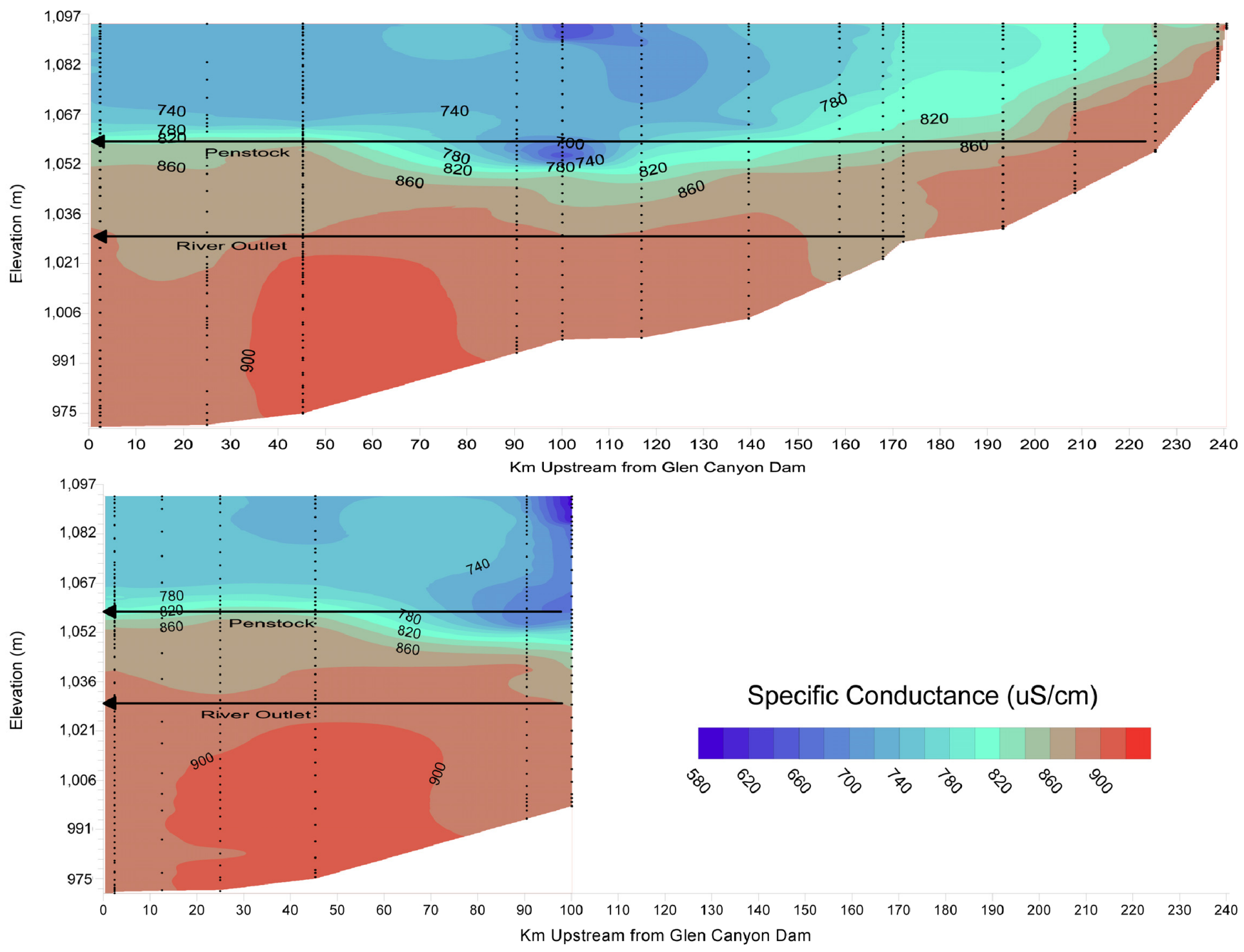

Figure 9. Isopleths of specific conductance in Lake Powell before (top) and after (bottom) the Glen Canyon Dam high-flow experiment, conducted March 5, 2008, through March 9, 2008. 

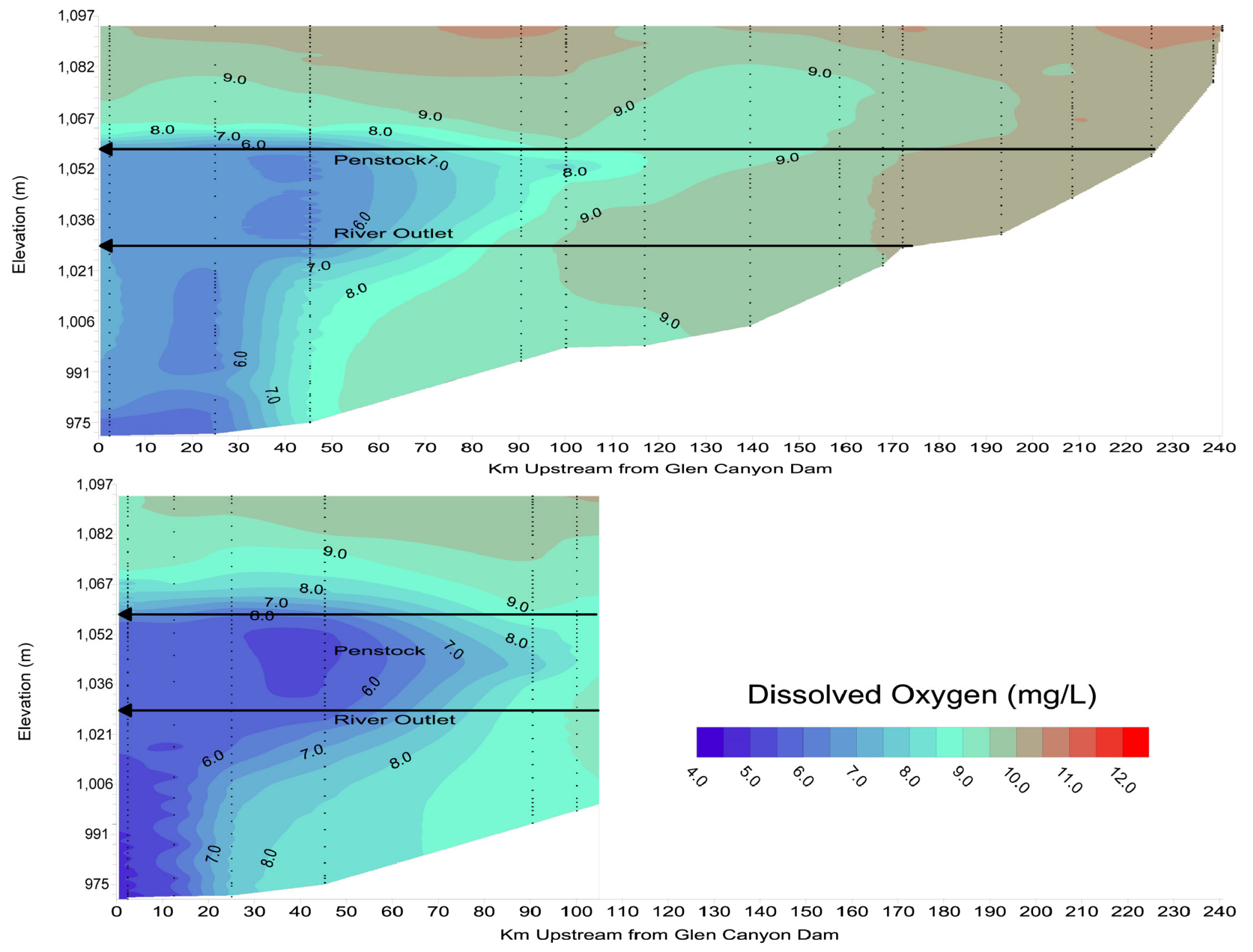

Figure 10. Isopleths of dissolved oxygen in Lake Powell before (top) and after (bottom) the Glen Canyon Dam high-flow experiment, conducted March 5, 2008, through March 9, 2008. 


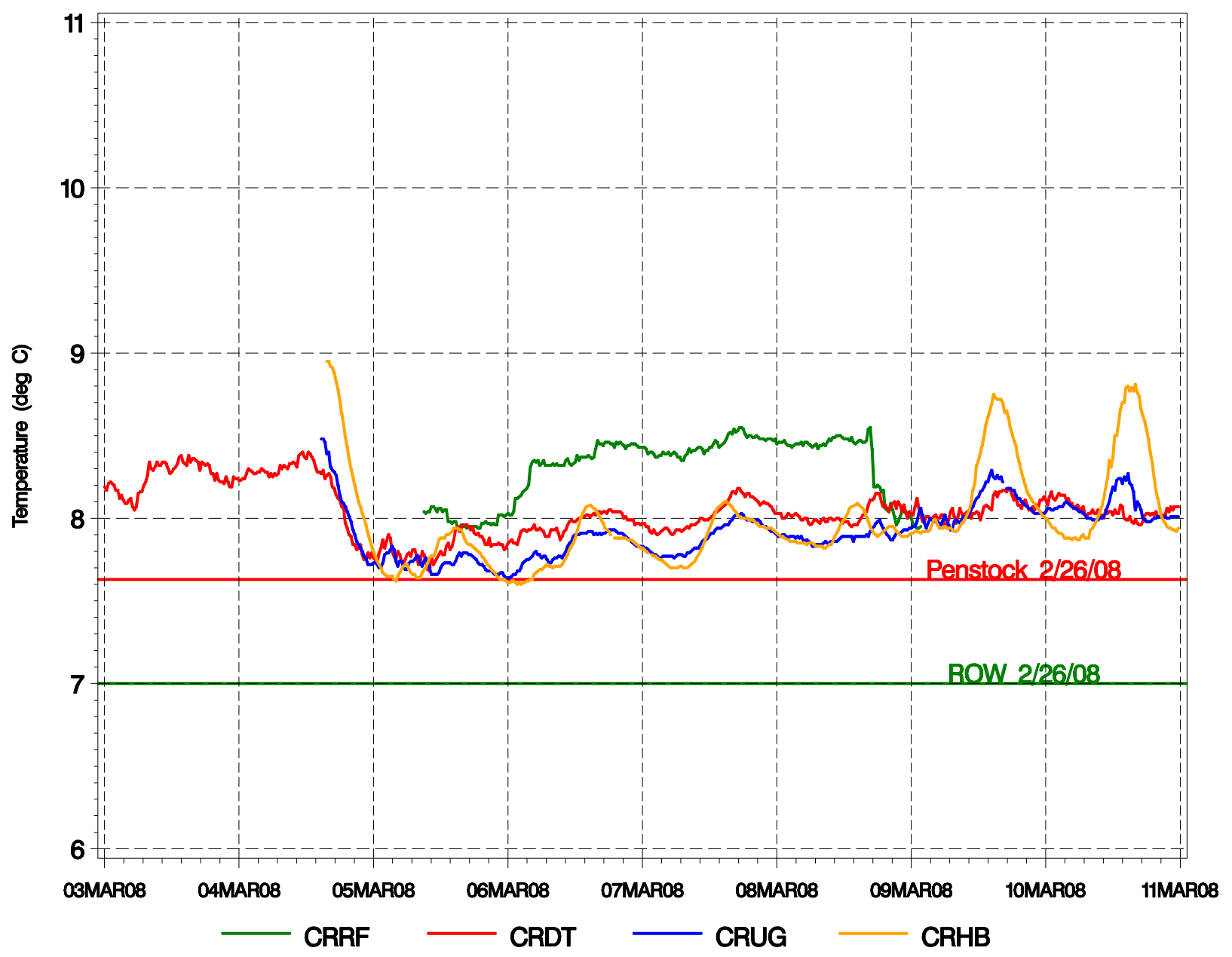

Figure 11. Combined water temperature in the tailwater before, during, and after the Glen Canyon Dam high-flow experiment, conducted March 5, 2008, through March 9, 2008. Horizontal lines indicate values from forebay profile of 2/26/2008. Temperatures at CRRF are artifactually high. (CRRF - ring-follower gate, CRDT - Glen Canyon Dam draft tube, CRUG - $1.8 \mathrm{~km}$ below Glen Canyon Dam, CRHB - $12.8 \mathrm{~km}$ below Glen Canyon Dam). 


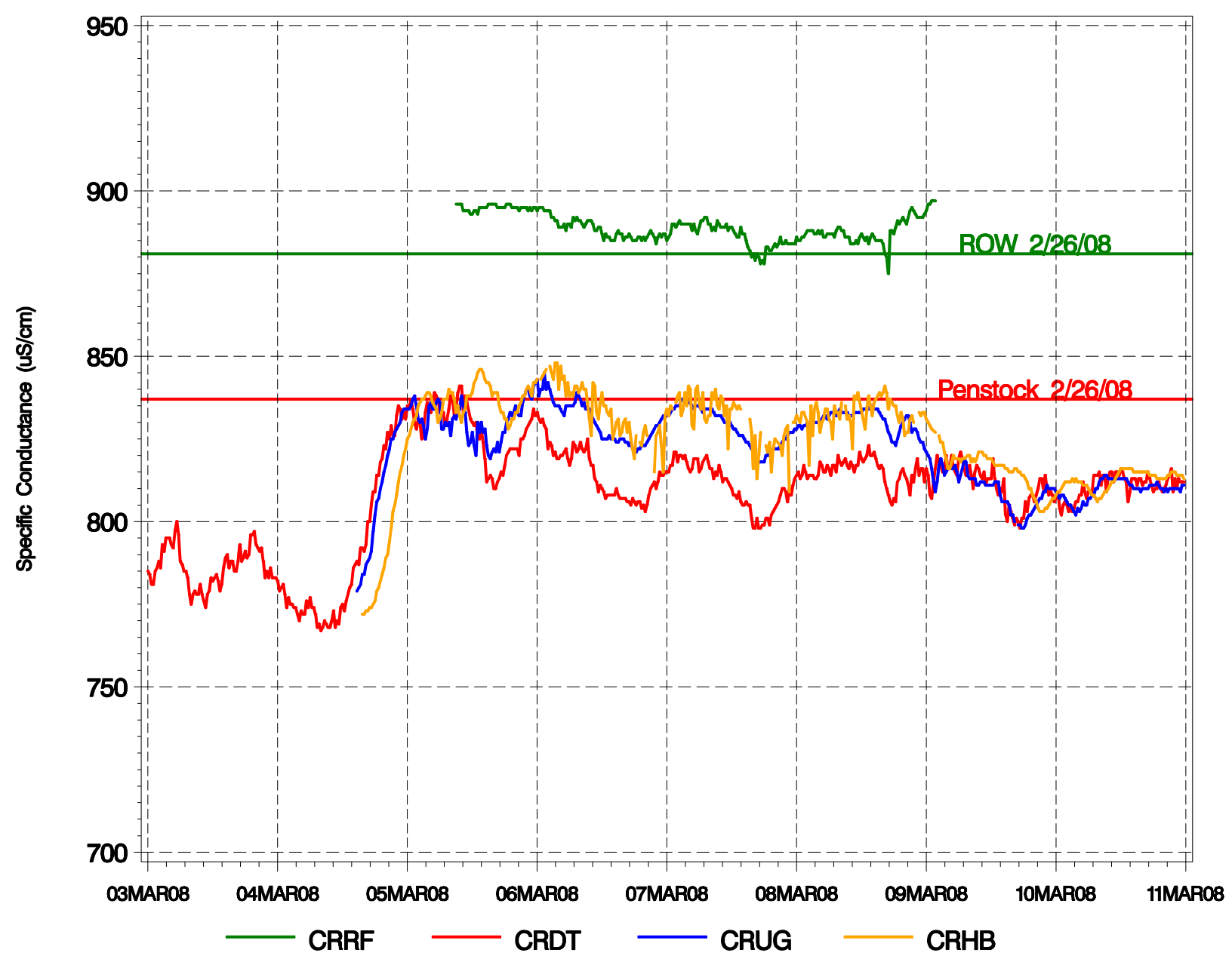

Figure 12. Combined specific conductance in the tailwater before, during, and after the Glen Canyon Dam highflow experiment, conducted March 5, 2008, through March 9, 2008. Horizontal lines indicate values from forebay profile of 2/26/2008. (CRRF - ring-follower gate, CRDT - Glen Canyon Dam draft tube, CRUG - 1.8 km below Glen Canyon Dam, CRHB - 12.8 km below Glen Canyon Dam). 


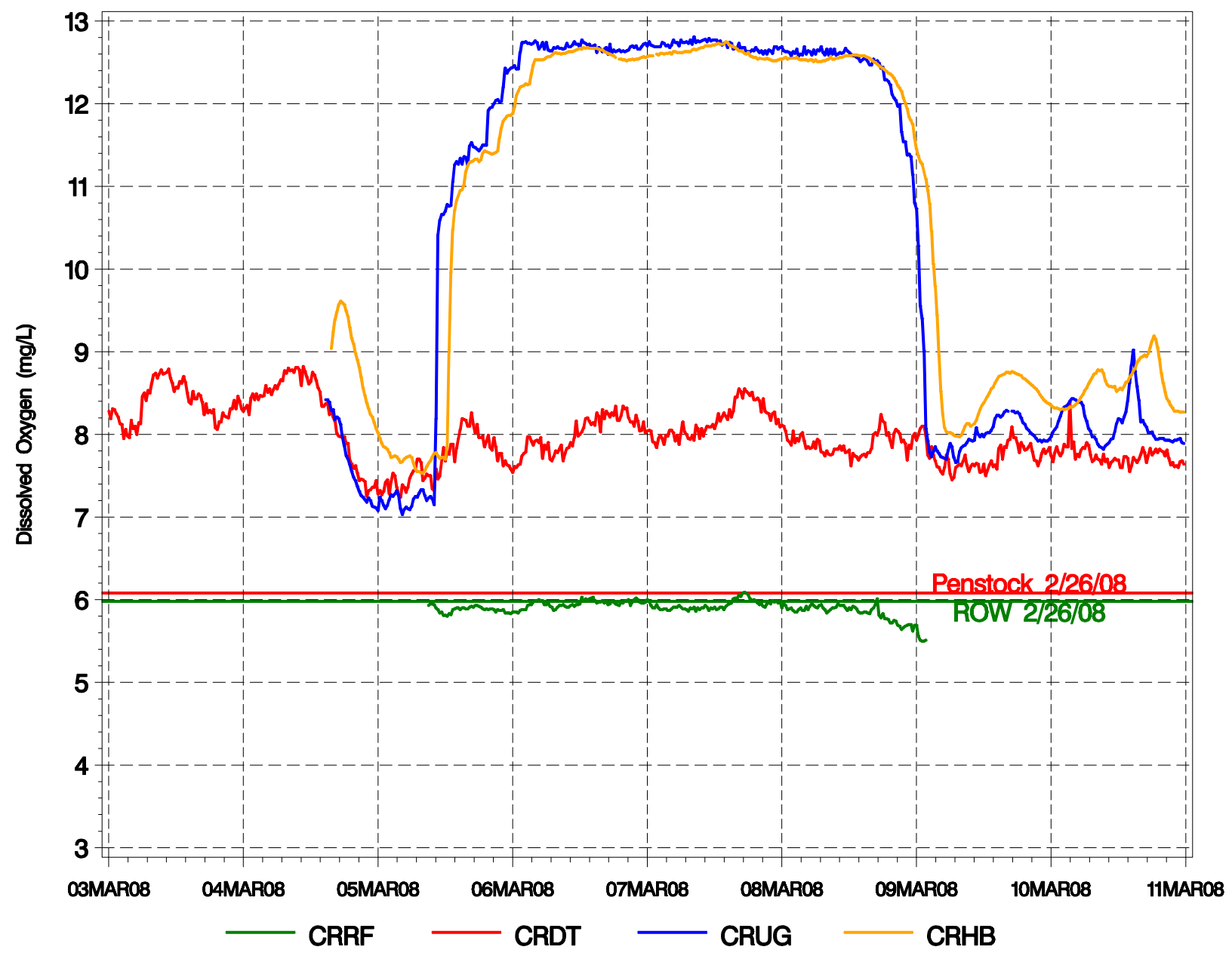

Figure 13. Combined dissolved oxygen concentrations in the tailwater before, during, and after the Glen Canyon Dam high-flow experiment, March 5, 2008, through March 9, 2008. Horizontal lines indicate values from forebay profile of 2/26/2008. (CRRF - ring-follower gate, CRDT - Glen Canyon Dam draft tube, CRUG - 1.8 km below Glen Canyon Dam, CRHB - 12.8 km below Glen Canyon Dam). 


\section{Tables}

Table 1. Lake Powell main channel monitoring locations. Station ID is a unique eight-character site identification code indicating a location's tributary arm and river-channel distance in kilometers $(\mathrm{km})$ upstream from Glen Canyon Dam (GCD).

\begin{tabular}{rlc}
\hline Station ID & \multicolumn{1}{c}{ Description } & $\begin{array}{c}\text { Distance upstream of GCD } \\
(\mathbf{k m})\end{array}$ \\
\hline LPCR0024 & Wahweap (GCD forebay) & 2.4 \\
LPCR0250 & Romano Narrows & 25.0 \\
LPCR0453 & Crossing of the Fathers & 45.3 \\
LPCR0905 & Oak Canyon & 90.5 \\
LPCR1001 & San Juan Confluence & 100.1 \\
\hline
\end{tabular}

Table 2. Tailwater monitoring locations and river-channel distance in kilometers $(\mathrm{km})$ downstream from Glen Canyon Dam (GCD).

\begin{tabular}{clc}
\hline $\begin{array}{c}\text { Station } \\
\text { Code }\end{array}$ & \multicolumn{1}{c}{ Description } & $\begin{array}{c}\text { Approximate distance } \\
\text { below GCD }(\mathbf{k m})\end{array}$ \\
\hline CRDT & Glen Canyon Dam Draft Tube \#6 & 0 \\
CRRF & Glen Canyon Dam Ring-Follower Gate & 0 \\
CRUG & USGS Gage below GCD & 1.8 \\
CRHB & Below Horseshoe Bend & 12.8 \\
\hline
\end{tabular}

Table 3. Lake Powell depth profiles before and after the Glen Canyon Dam high-flow experiment, March 5, 2008, through March 9, 2008.

To download table 3, please visit http://pubs.usgs.gov/of/2010/1159/.

Table 4. Average values of water temperature (T), specific conductance (SC), and dissolved oxygen (DO) at selected locations during the Glen Canyon Dam high-flow experiment (HFE), conducted March 5, 2008, through March 9, 2008. (CRRF - ring-follower gate, CRDT - Glen Canyon Dam draft tube, CRUG - $1.8 \mathrm{~km}$ below Glen Canyon Dam, CRHB - $12.8 \mathrm{~km}$ below Glen Canyon Dam). Lake Powell measurements were collected on February 26, 2008. Combined release was calculated using a discharge-weighted average of CRDT and CRRF.

\begin{tabular}{lrrr}
\multicolumn{1}{c}{ Location } & $\begin{array}{c}\text { T } \\
\text { (deg C) }\end{array}$ & $\begin{array}{c}\text { SC } \\
(\boldsymbol{\mu S / \mathbf { c m } )}\end{array}$ & \multicolumn{1}{c}{$\begin{array}{c}\text { DO } \\
(\mathbf{m g} / \mathbf{L})\end{array}$} \\
\hline Lake Powell - Penstock Elevation 1058 m & 7.63 & 837 & 6.08 \\
Lake Powell - ROW elevation 1028 m & 7.00 & 881 & 5.98 \\
CRDT (mean during HFE period) & 8.00 & 812 & 8.04 \\
CRRF (mean during HFE period) & 8.43 & 887 & 5.93 \\
Combined release (calculated) & 8.16 & 840 & 7.26 \\
CRUG (mean during HFE period) & 7.87 & 829 & 12.70 \\
CRHB (mean during HFE period) & 7.88 & 831 & 12.60 \\
\hline
\end{tabular}


Table 5. Values of water temperature (T), specific conductance (SC), and dissolved oxygen (DO) at selected locations before, during, and after the Glen Canyon Dam high-flow experiment (HFE), conducted March 5 , 2008, through March 9, 2008. (CRRF - ring-follower gate, CRDT - Glen Canyon Dam draft tube, CRUG - 1.8 km below Glen Canyon Dam, CRHB - 12.8 km below Glen Canyon Dam).

To download table 5, please visit http://pubs.usgs.gov/of/2010/1159/.

\section{References Cited}

Ferrari, R.L., 1988, 1986 Lake Powell survey: Denver, Colo., Bureau of Reclamation, report no. RECERC-88-6, 67 p. [Available from National Technical Information Service, Springfield, Va. as NTIS Report PB89-178818.]

Hart, R.J., and Sherman, K.M., 1996, Physical and chemical characteristics of Lake Powell at the forebay and outflow of Glen Canyon Dam, northeastern Arizona, 1990-91: U.S. Geological Survey Water-Resources Investigations Report 96-4016, 78 p.

Hueftle, S.J., and Stevens, L.E., 2001, Experimental flood effects on the limnology of Lake Powell reservoir, Southwestern USA: Ecological Applications, v. 11, no. 3, p. 644-656.

Schmidt, J.C., 1999, Summary and synthesis of geomorphic studies conducted during the 1996 controlled flood in Grand Canyon, in Webb, R.H., Schmidt, J.C., Marzolf, G.R., and Valdez, R.A., eds., The controlled flood in Grand Canyon-scientific experiment and management demonstration, v. 110: Washington, D.C., American Geophysical Union, Geophysical Monograph Series, ISBN: 0-87590-093-3, p. 329-341.

U.S. Geological Survey, 2007, Science plan for potential 2008 experimental high flow at Glen Canyon Dam: U.S. Geological Survey, Grand Canyon Monitoring and Research Center, p. 104, accessed on January 14, 2010, at http://www.usbr.gov/uc/envdocs/ea/gc/2008hfe/index.html.

Vernieu, W.S., 2009, Physical and chemical data for water in Lake Powell and from Glen Canyon Dam releases, Utah-Arizona, 1964-2008: U.S. Geological Survey Data Series 471, 23 p. and database, accessed on February 1, 2010, at http://pubs.usgs.gov/ds/471/.

Vernieu, W.S., Hueftle, S.J., and Gloss, S.P., 2005, Water quality in Lake Powell and the Colorado River, in Gloss, S.P., Lovich, J.E., and Melis, T.S., eds., The state of the Colorado River ecosystem in Grand Canyon: U.S. Geological Survey Circular 1282, 69-85 p., accessed on May 10, 2010, at http://pubs.usgs.gov/circ/1282/.

Water and Power Resources Service, 1981, Colorado River Storage Project, in Water and Power Resources Service - project data: Denver Colo., U.S. Department of the Interior, Water and Power Resources Service, p. 355-372. 
This page was intentionally left blank. 
몽

$\stackrel{9}{\exists}$

욜 